\title{
A Review of Bonding Immiscible Mg/Steel Dissimilar Metals
}

\author{
Gang Song ${ }^{\circledR}$, Taotao $\mathrm{Li}^{*}$, Jingwei Yu and Liming Liu
}

Key Laboratory of Liaoning Advanced Welding and Joining Technology, School of Material Science and Engineering, Dalian University of Technology, Dalian 116024, China; songgang@dlut.edu.cn (G.S.); yujw@mail.dlut.edu.cn (J.Y.); liulm@dlut.edu.cn (L.L.)

* Correspondence: lin_tao@mail.dlut.edu.cn; Tel.: +86-411-8470-7817

Received: 29 September 2018; Accepted: 29 November 2018; Published: 11 December 2018

\begin{abstract}
The challenge of joining immiscible $\mathrm{Mg} /$ Steel dissimilar metals lies in the absence of an Fe-Mg intermetallic or Fe-Mg solid solution in an Mg-Fe system, and differences in their physical and chemical properties. Promoting interfacial reaction and regulating the composition of interface layer are beneficial for the formation of an $\mathrm{Mg}$ /steel interface layer and to obtain an effective $\mathrm{Mg} /$ steel joint. This research work focusses on the bonding of immiscible $\mathrm{Mg}$ /steel dissimilar metals: First, an $\mathrm{Mg}$ /steel interface layer was designed by controlling the composition of added alloy elements and trace elements in the base metal. Second, the $\mathrm{Mg}$ /steel dissimilar metals welding methods were divided into three parts—-solid state welding, welding-brazing and fusion welding. The main distinctions between them were difference in interfacial temperature, thickness of interface layer, and type of compound. Third, the orientation relationships (OR) of the $\mathrm{Mg}$ /interface layer system and the interface layer/steel system was investigated. In this review, the effect of welding processing parameters, addition of alloy elements, base metal, and different welding methods on the joint's performance was studied. The mechanical property, microstructure, interface layer and metallurgical reactions of the joint were also examined. The most recent progress in joining immiscible $\mathrm{Mg} / \mathrm{Steel}$ dissimilar metals and future research prospects are presented at the end of the paper.
\end{abstract}

Keywords: Mg alloy; steel; welding; $\mathrm{Mg}$ /steel interface; mechanical property

\section{Introduction}

\subsection{Background}

$\mathrm{Mg}$ alloy has gradually become a competitive new light structural material. It is now being widely used in the fields of electronic communication, automobile, and aerospace. Steel materials will continue to occupy a dominant position in the application of industrial production with the successful development of high-strength steel. Some steel structures were possibly replaced by lightweight metals because of the rapid increase of lightweight structural materials. The application of lightweight materials in the automotive industry has become common. Automotive companies are using lightweight materials to create better and more-developed automobiles. Dissimilar metal hybrid structures combine the advantages of two metals (such as $\mathrm{Al} /$ steel [1], $\mathrm{Al} / \mathrm{Mg}$ [2], $\mathrm{Al} / \mathrm{Cu}$ [3], $\mathrm{Al} / \mathrm{Ti}$ [4], Ti/steel [5,6] and Mg/steel hybrid structures [7], etc), and can achieve the purpose of being lightweight while satisfying operating requirements.

\subsection{The Challenge of $\mathrm{Mg} /$ Steel Welding}

The physical and chemical properties of $\mathrm{Mg}$ and Fe are shown in Table 1. The huge differences between $\mathrm{Mg}$ and Fe lead to the following challenges for $\mathrm{Mg} /$ steel joints. 
(1) $\mathrm{Mg} /$ steel joint welding was not similar to the $\mathrm{Al} /$ steel and $\mathrm{Al} / \mathrm{Mg}$ joint. A large number of $\mathrm{Fe}-\mathrm{Al}$ compounds are detected in the $\mathrm{Al} / \mathrm{Fe}$ joint, which influence the $\mathrm{Al} / \mathrm{Fe}$ joint performance. However, there was no intermetallic compound (IMC) forming in the $\mathrm{Mg} / \mathrm{Fe}$ joint, and little solid solubility in the Mg-Fe system (Figure 1). Therefore, it was difficult to form an interface layer and obtain an effective $\mathrm{Mg} /$ steel joint.

(2) The melting point of Fe (about $1811 \mathrm{~K}$ ) is much higher than the boiling point of $\mathrm{Mg}(1363 \mathrm{~K})$. $\mathrm{Mg}$ is directly evaporated as steel melting. The thermal expansion coefficient of $\mathrm{Mg}$ is more than twice as big as that of Fe. For these reasons, heat input and welding distortion are particularly important during the $\mathrm{Mg}$ /steel welding process.

Table 1. The physical and chemical properties of $\mathrm{Mg}$ and Fe [8].

\begin{tabular}{ccc}
\hline Properties & Mg & Fe \\
\hline Crystal structure & hexagonal close-acked & body-centered cubic and face-centered cubic \\
Atomic radius $(\mathrm{pm})$ & 160 & 126 \\
Melting point $(\mathrm{K})$ & 923 & 1811 \\
Boiling point $(\mathrm{K})$ & 1363 & 3134 \\
Thermal conductivity $(\mathrm{W} /(\mathrm{m} \cdot \mathrm{K}))$ & 156 & 80.4 \\
Young's modulus $(\mathrm{GPa})$ & 45 & 211 \\
Thermal expansion $(\mu \mathrm{m} /(\mathrm{m} \cdot \mathrm{K}))\left(\right.$ at $\left.25^{\circ} \mathrm{C}\right)$ & 24.8 & 11.8 \\
Density $\left(\mathrm{g} / \mathrm{cm}^{3}\right)$ & 1.738 & 7.874 \\
Heat of vaporization $(\mathrm{kJ} / \mathrm{mol})$ & 128 & 340 \\
Heat of fusion $(\mathrm{kJ} / \mathrm{mol})$ & 8.48 & 13.81 \\
\hline
\end{tabular}
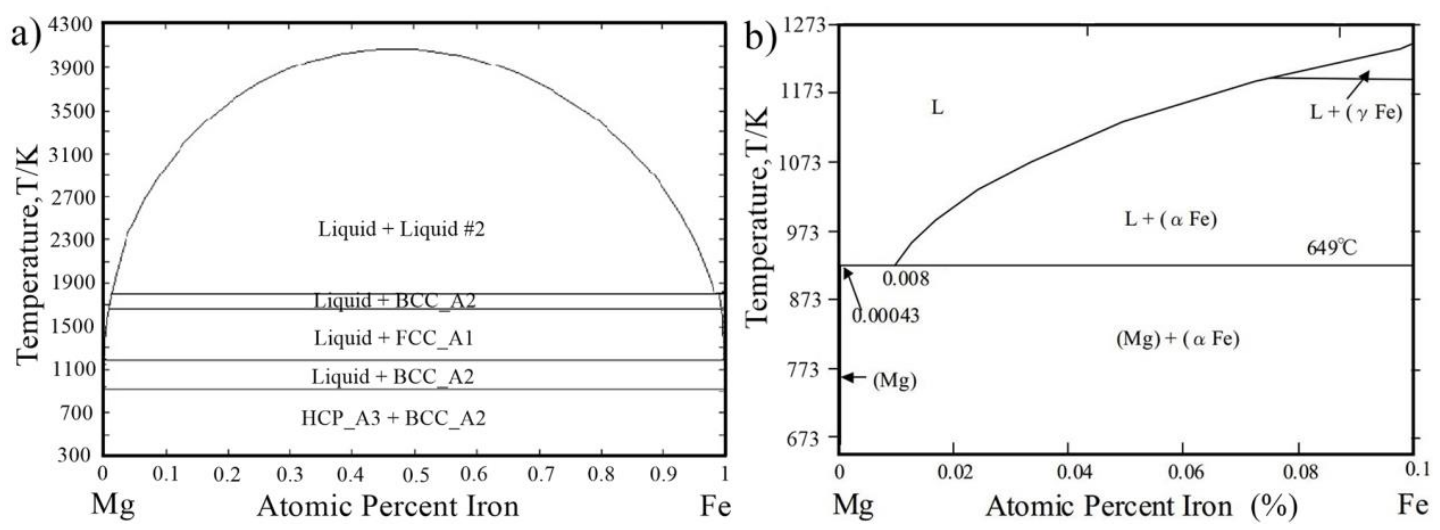

Figure 1. Mg-Fe binary phase diagram [9].

\subsection{Research Status and Progress}

The challenges of bonding immiscible Mg/Steel dissimilar metals are no Fe-Mg IMCs and little solid solubility in the Mg-Fe system, and obvious differences in the physical and chemical properties of $\mathrm{Mg}$ and Fe. Hence, knowing how to obtain an interface layer with certain thickness is the key to the bonding of immiscible $\mathrm{Mg} /$ Steel dissimilar metals. Promoting interfacial reaction could form a $\mathrm{Mg}$ /steel interface layer and obtain an effective $\mathrm{Mg}$ /steel joint. At present, the research on joining immiscible $\mathrm{Mg}$ /steel dissimilar metals mainly focuses on the following aspects. First, the elements of the interface layer mainly come from the base metal or by adding alloy elements. Therefore, the purpose of designing different types of interface layers could be achieved by choosing different components of the base metal and suitable alloy elements, such as, Mg base filler wires (AZ31, AZ61 and $\mathrm{AZ91}$ ) and interlayer ( $\mathrm{Al}, \mathrm{Cu}, \mathrm{Ni}, \mathrm{Cu}-\mathrm{Zn}$ foil layers or $\mathrm{Ni}, \mathrm{Zn}$, Sn coatings, et al.). The alloy elements could form IMCs or solid solutions with $\mathrm{Mg}$ and Fe may be used as a criterion, such as $\mathrm{Al}$, $\mathrm{Cu}, \mathrm{Ni}, \mathrm{Zn}, \mathrm{Cu}, \mathrm{Sn}$, not Ti and V (no IMCs or solid solutions with Mg), etc. Secondly, the change of interfacial temperature has an important influence on the type and thickness of the interface layer, such as Mg-Zn low melting point eutectic being detected near the $\mathrm{Mg} /$ steel interface during solid state welding, the melting point of IMC $\left(\mathrm{Al}_{8} \mathrm{Mn}_{5}\right)$ nearly $\mathrm{Mg}$ boiling point being detected near the $\mathrm{Mg} /$ steel interface during welding-razing, and the high melting point phase (AlNi) detected near 
the $\mathrm{Mg} /$ steel interface during fusion welding. Lastly, the interface layers were mainly composed of IMCs. Different IMCs exist in the Mg/steel interface, which exhibited different mechanical properties. An edge-to-edge matching model is used for predicting orientation relationships (OR) of $\mathrm{Mg} / \mathrm{IMC}$ and IMC/steel, which could characterize interface bonding strength. Based on the above ideas, design and control of the composition of interface layer could obtain a better $\mathrm{Mg}$ /steel joint. No matter which way was adopted to weld $\mathrm{Mg}$ alloy and steel, a better $\mathrm{Mg}$ /steel joints could be obtained, and some techniques were found to be very promising. A detailed discussion on the research of bonding immiscible $\mathrm{Mg} /$ steel dissimilar metals is presented in the following section.

\section{Solid State Processes}

\subsection{Friction Stir Welding}

Friction stir welding (FSW) produces heat between the pin and the shoulder, which melts the plastic in the workpiece. The stir head rotates, mixes, and moves in the welding direction. At the same time, a metallurgical reaction takes place at the interface of dissimilar metals. FSW ensures that the joint has no related melting welding defects, and thermal deformation and residual stress is small. Immiscible $\mathrm{Mg}$ /steel dissimilar metals can be bonded by this technology. The $\mathrm{Zn}$ coating is key to obtaining effective joints during most $\mathrm{Mg} /$ steel friction stir welding [10-14]. The purpose of $\mathrm{Zn}$ coating is to remove the oxide film and squeeze the new $\mathrm{Zn}$ phase to the edge, which could improve the weldability of $\mathrm{Mg} /$ steel.

Figure 2 shows the typical Mg/steel lap joint by FSW [15]; it is seen that the process stirs some steel particles in the Mg alloy stir zone [16-19]. The bonding mechanism of $\mathrm{Mg}$ /steel is mainly divided into two types: First, the Mg-Zn low melting point eutectic formed near the $\mathrm{Mg}$ /steel interface by the intervention of $\mathrm{Zn}$ coating, as shown in Figure 3 [20]. The forge force could obtain $8.2 \mathrm{kN}$ at a higher welding speed, which was higher than that of the lower welding speed. This study showed that the forced material flow by stirring (not welding speed) was the main reason why the liquid layer flows out of the interface.
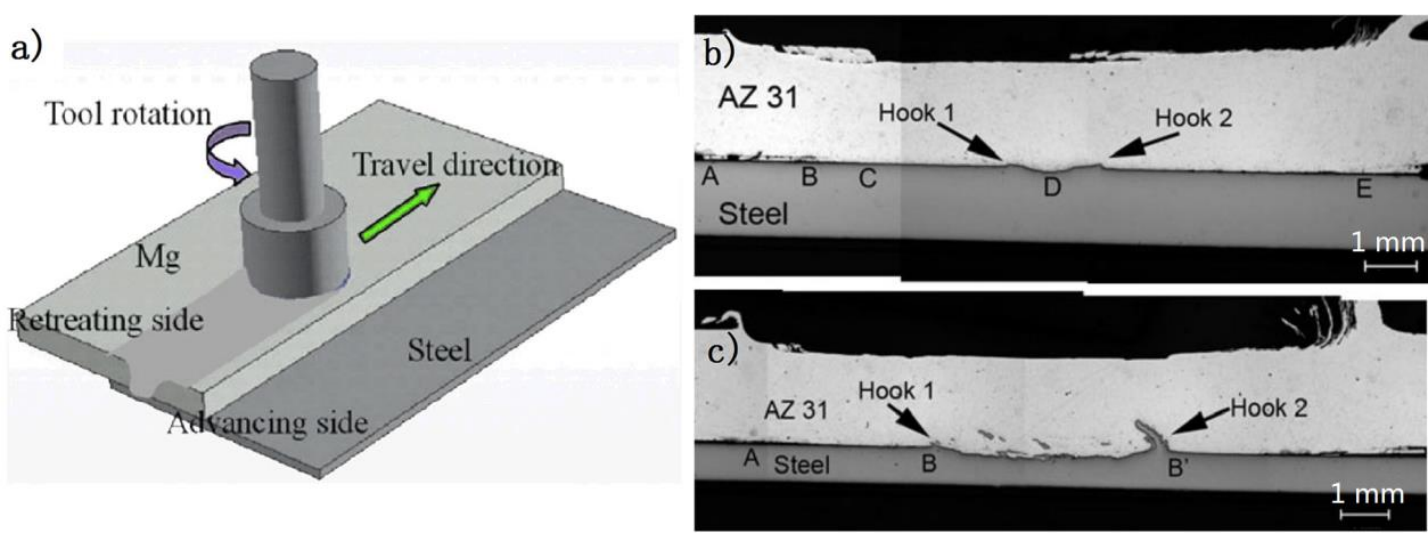

Figure 2. Friction stir lap welding process [15] (a) schematic illustrations; (b,c) cross-sectional macrograph of AZ31 to $1.5 \mathrm{~mm}$ and $0.8 \mathrm{~mm}$ steel weld. 

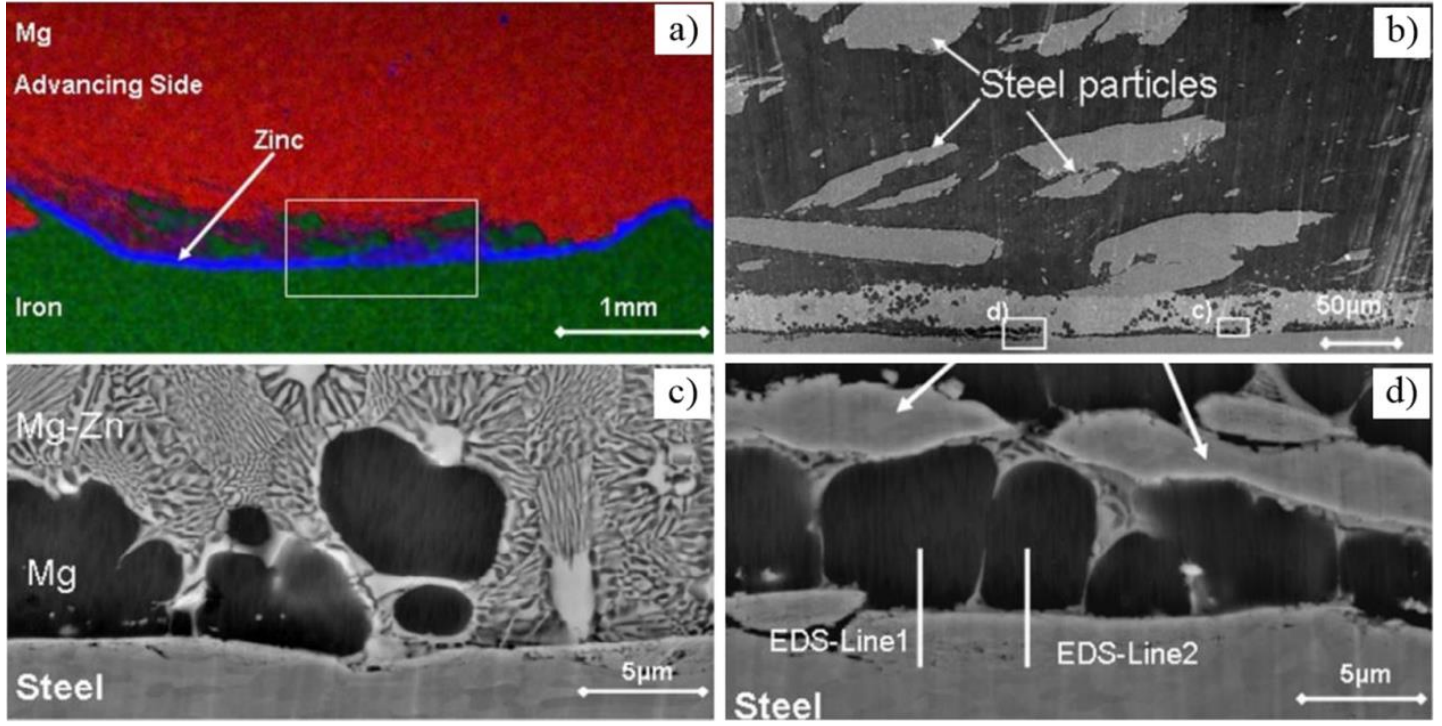

Figure 3. FSW $\mathrm{Mg} / \mathrm{Zn}$ coated steel process [20] (a) EDX map of cross-section; (b) stir zone near $\mathrm{Mg} /$ steel interface; (c,d) enlarged drawing in (b).

Second, the liquid reaction products were extruded far from the center of the weld, spreading along the interface and then piling into the joining interface [14]. Low melting point eutectic was squeezed out of the $\mathrm{Mg}$ /steel interface, clearing the steel surface. This helps promote mutual diffusion in $\mathrm{Mg}$ alloy/steel layers. The Mg-Zn layer was formed at the side of the mechanically bonded region, as shown in Figure 4. This increased width of the mechanically bonded region may be responsible for producing joint strengths close to the parent material strength. Since the FSW tool vigorously stirred and fragmented the bottom of the electro-galvanized steel sheet welding joint, there was no opportunity for the molten $\mathrm{Zn}$ coating to flow laterally at several locations. As a result, a $\mathrm{Zn}-\mathrm{Mg}$ solidified phase formed at those regions. The results of $\mathrm{Mg}, \mathrm{Zn}, \mathrm{Al}$ and Fe linear SEM-EDS is shown in Figure $4 \mathrm{~b}$. The $\mathrm{Al}$ element was enriched in the $\mathrm{Mg}$ /steel interface, and the $\mathrm{Zn}$ element changed little along the EDS analysis results. The $\mathrm{Mg}$ /steel lap joints failed at the $\mathrm{Mg}$ /steel interface. The common IMCs at the $\mathrm{Mg}$ /steel interface were: $\mathrm{Fe}_{4} \mathrm{Al}_{13}$ and $\mathrm{Fe}_{3} \mathrm{Al}$ [13,17-19,21], $\mathrm{Fe}_{2} \mathrm{Al}_{5}$ [10] and $\mathrm{FeAl}_{2}$ [12]. These results show that the intervention of $\mathrm{Zn}$ improved the interface bonding state of $\mathrm{Mg} / \mathrm{steel}$ lap joints.
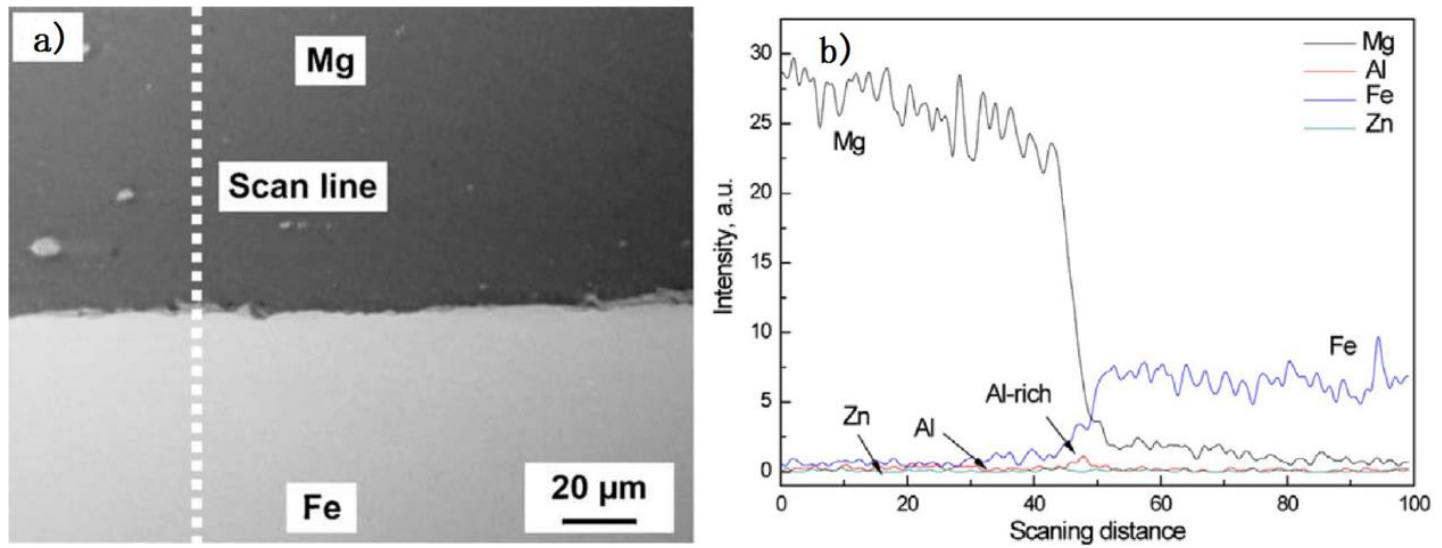

Figure 4. FSW Mg/Zn coated steel process [17] (a,b) SEM micrographs near Mg/steel interface and EDS analysis results along the scan line in (a).

FSW technical was also adopted to weld a Mg/steel butt joint. Kasai et al. [22] studied the effect of $\mathrm{Al}$ content in the $\mathrm{Mg}$ alloy on the mechanical properties of steel/Mg butt joint by FSW. From Figure 5, 
it is evident that maximum tensile strength appeared in the AZ61/steel butt joint. The higher the Al content (pure Mg, AZ31 and AZ61 Mg alloy), the greater the tensile strength of the joint was. The Al elements played a key role in bonding $\mathrm{Mg}$ /steel dissimilar metals [23]. The Fe- $\mathrm{Al} \mathrm{IMC}\left(\mathrm{Fe}_{2} \mathrm{Al}_{5}\right)$ layer was formed at the $\mathrm{Mg}$ / steel interface and primarily detected in AZ series $\mathrm{Mg}$ alloy/steel joints. Besides, the thickness of the interface layer also had a great influence on the strength of joints. The thinner the interface layer, the greater strength of the joint.

a)
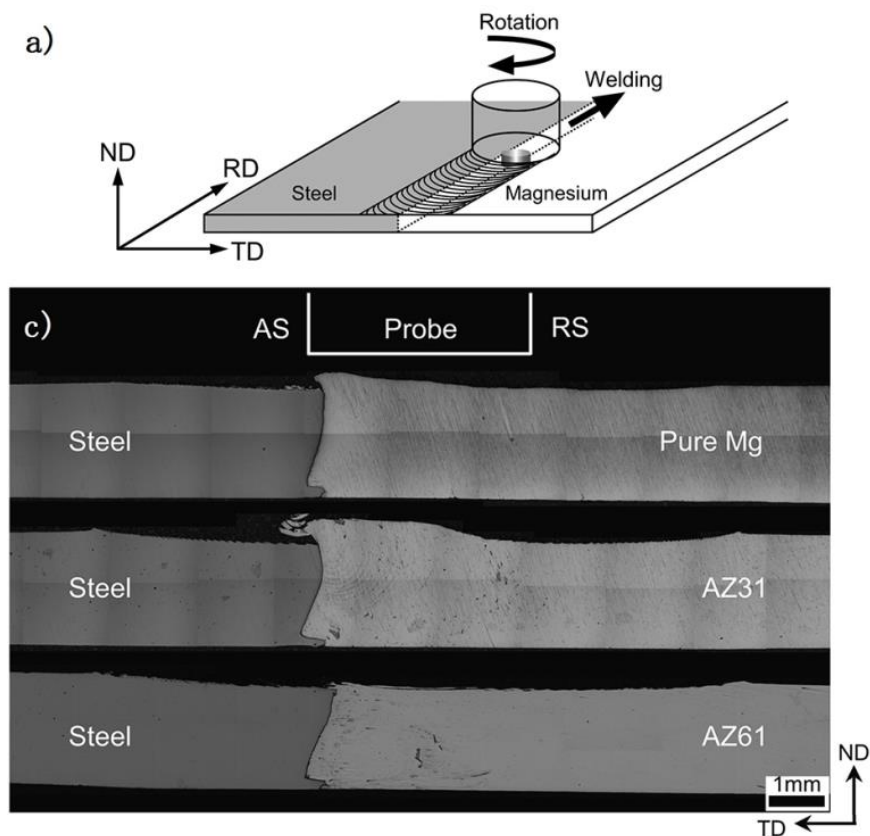

b)
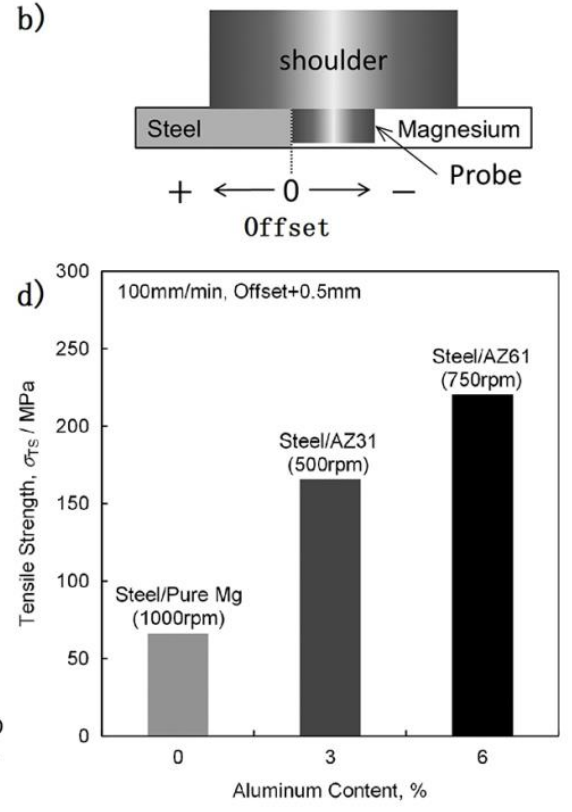

Figure 5. FSW Mg/steel butt joint process [22] (a) schematic illustrations; (b) tool offset position; (c) OM images of the interfaces on the cross section; (d) relationship between the optimal tensile strength of the joint and Al content.

By optimizing the welding parameters to obtain excellent $\mathrm{Mg}$ /steel FSW joints, the maximum shear load of $2.9 \mathrm{kN}$ was obtained by AM60/galvanized DP600 steel friction stir spot welding (FSSW) joints [24]. The shear load of AZ31/galvanized Q235 steel FSSW joint reached $4.3 \mathrm{kN}$ with pre-existing $\mathrm{Fe}_{2} \mathrm{Al}_{5}$ on the surface of the steel. ZEK100 Mg alloy and Zn coated DP600 steel was welded by refill FSSW and obtained $4.7 \mathrm{kN}$ shear load [12]. AZ31B/galvanized mild steel joints were welded by friction stir keyholeless spot welding and obtained maximum shear strength of $8.7 \mathrm{kN}$ [13]; the AZ31B/DP600 galvanized steel joints reached $8.7 \mathrm{kN}$ [25] and $10.36 \mathrm{kN}$ [11]. AZ31 Mg alloy and low carbon Zn coated steel joints obtained maximum failure loads of $2.3 \mathrm{kN}$ [19] and $3.4 \mathrm{kN}$ (65\% of steel base metal) [18] by friction stir lap welding. The maximum shear strength of the AZ31/1.5 mm hot-dipped galvanized steel joints was found to be $7.07 \mathrm{kN}$ [15]. AZ31B/Zn coated ultralow carbon steel lap joints could reach $8.2 \mathrm{kN}$ for a higher welding speed [20]. In summary, there were several factors affecting the performance of the $\mathrm{Mg}$ /steel joint; they included a suitable IMC preset on the steel surface, adoption of friction stir keyholeless welding technology, and choice of Zn-coated steel.

In addition, the fatigue behavior of $\mathrm{Mg}$ /steel friction stir spot welds was also studied [14,26], as shown in Figure 6. AZ31/low carbon steel sheets dissimilar metals were successfully welded by FSSW without a probe, and the tensile-shear fatigue strength of $\mathrm{Mg}$ /steel joint was comparable to $\mathrm{Mg} / \mathrm{Mg}$ welds [26]. ZEK $100 \mathrm{Mg}$ alloy/galvanized DP600 steel sheets was welded by refill FSSW [14]. Most of the fatigue fractures were broken at the $\mathrm{Mg}$ /steel interface, except stress $1087 \mathrm{~N} \leq P_{\max } \leq 1812 \mathrm{~N}$, whose fatigue fractures occurred at the $\mathrm{Mg}$ alloy base metal. 

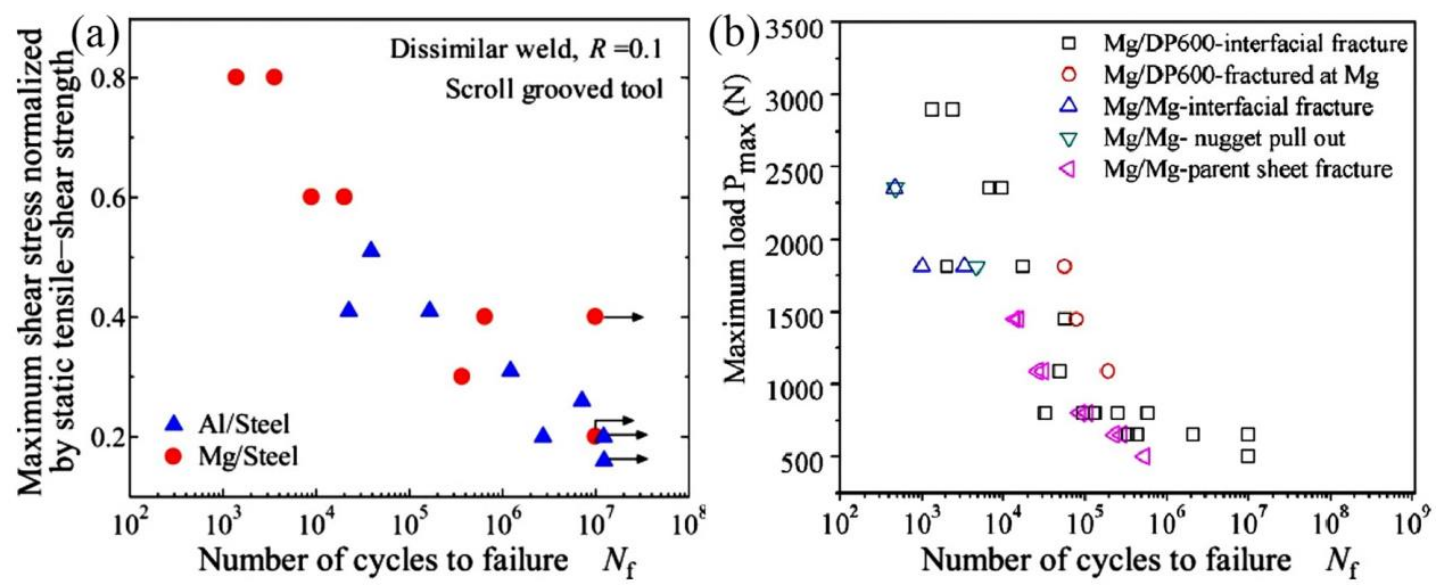

Figure 6. Relationship between maximum load and number of cycles to failure (a) Mg alloy/steel friction stir spot welds [26]; (b) $\mathrm{Mg}$ / steel dissimilar refill friction stir spot welds [14].

\subsection{Diffusion Bonding}

Diffusion bonding is a typical solid state technique suitable for joining $\mathrm{Mg}$ /steel dissimilar metals. The diffusion welding of $\mathrm{Mg}$ /steel is mainly based on the lap joint. It aims to close the workpiece surface at a high temperature and under a certain pressure, and to maintain a period of time to realize the mutual diffusion between the atoms in the workpiece surface. In the bonding of some dissimilar metals with little mutual solubility, the method of adding interlayers can be used to obtain a reliable and effective bonding. The advantage of this welding method is that welding temperature is low, and dissimilar materials can be bonded without damage to the properties of the base metal. Besides, welding deformation is small, and joint composition and organization is uniform. The determined influence on shear load of the joints was bonding time and temperature, followed by surface roughness and bonding pressure. There is no IMC between $\mathrm{Mg} /$ steel. Therefore, an interlayer should be added to achieve effective bonding between them.

As mentioned above, the interlayer is used as a bridge to promote the metallurgical bonding of $\mathrm{Mg}$ /steel joint. Ni and $\mathrm{Cu}$ were primary selected as the interlayer to join $\mathrm{Mg}$ alloy and steel, because they offer metallurgical compatibility with $\mathrm{Mg}$ and Fe. Different microstructures and bonded interface layer are formed under different interlayers.

Elthalabawy et al. $[27,28]$ used $\mathrm{Ni}$ interlayer and studied the microstructural evolution of double stage diffusion-brazed $316 \mathrm{~L}$ austenitic stainless steel to AZ31 Mg alloy. The effect of bonding times on joint microstructural evolution is shown in Figure 7a-e. A maximum shear strength of $46 \mathrm{MPa}$ was obtained at $510{ }^{\circ} \mathrm{C}$ with $20 \mathrm{~min}$ bonding time, because of a eutectic phase surrounding the intermetallic B2 particles. To further improve the shear strength of $\mathrm{Mg} /$ steel joint, the double stage bonding of $316 \mathrm{~L} / \mathrm{Ni} / \mathrm{AZ31}$ was adopted [27]. A solid-state Ni-Fe reaction layer preexisted on the steel surface. The Ni-Fe reaction layer on the steel surface bonds the interfacial structure after diffusion, instead of the Fe. The experimental results showed that the joint region reveals a thin reaction layer representing the $\mathrm{Mg}_{2} \mathrm{Ni} \mathrm{IMC}$ and $\mathrm{Mg}-\mathrm{Ni}$ eutectic phase (E). The maximum value of joint shear strength was $54 \mathrm{MPa}$ by double stage diffusion brazing owing to the solid-state $\mathrm{Ni}$-Fe reaction layer.

A pure $\mathrm{Cu}$ interlayer was also studied in the microstructural characteristics of $\mathrm{AZ} 31 / \mathrm{Cu} / 316 \mathrm{~L}$ joint by diffusion-brazing $[29,30]$. The effect of bonding time on microstructural evolution and bond shear strength were studied at $530^{\circ} \mathrm{C}$. The bonding process took place through a sequential occurrence of solid state diffusion of $\mathrm{Cu}$ into the $\mathrm{Mg}$ alloy, eutectic phase formation, interlayer dissolution, and isothermal solidification. The $\lambda_{1}(\mathrm{Mg}-\mathrm{Cu}-\mathrm{Al})$ ternary intermetallic phase formed within the joint and concentrated into the center of the bond during the solidification stage is shown in Figure 8. The packing of the intermetallic $\left(\lambda_{1}\right)$ had a significant effect on the change of bond shear strength. The maximum shear strength $57 \mathrm{MPa}$ was obtained at $510{ }^{\circ} \mathrm{C}$ with 20 min bonding time. 

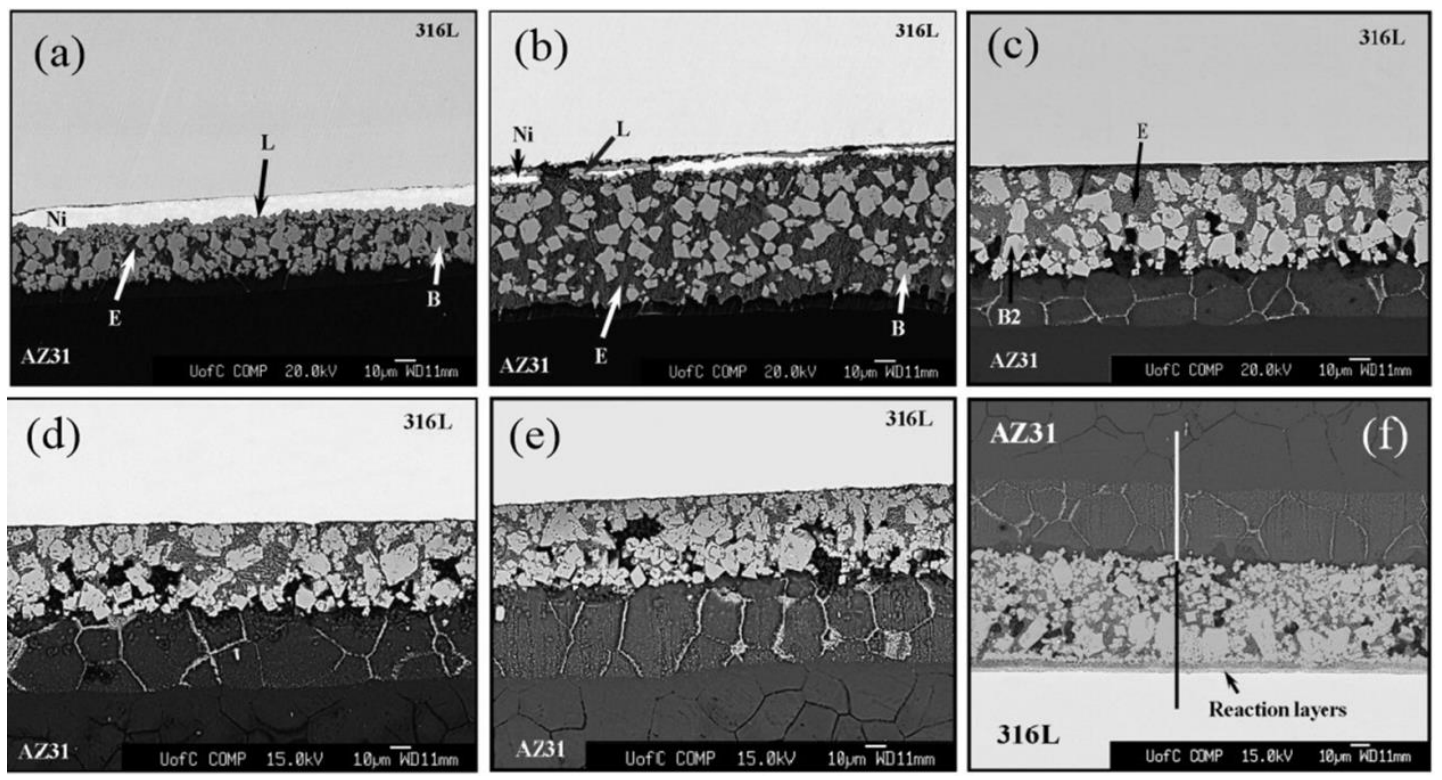

Figure 7. SEM micrographs of $\mathrm{AZ31} / \mathrm{Ni} / 316 \mathrm{~L}$ joint at $510{ }^{\circ} \mathrm{C}$ with different bonding time [27] (a) 3 min; (b) $5 \mathrm{~min}$; (c) $10 \mathrm{~min}$; (d) $20 \mathrm{~min}$; (e) $30 \mathrm{~min}$; (f) double stage bonding of $316 \mathrm{~L} / \mathrm{Ni} / \mathrm{AZ} 31$ with $20 \mathrm{~min}$ bonding time.
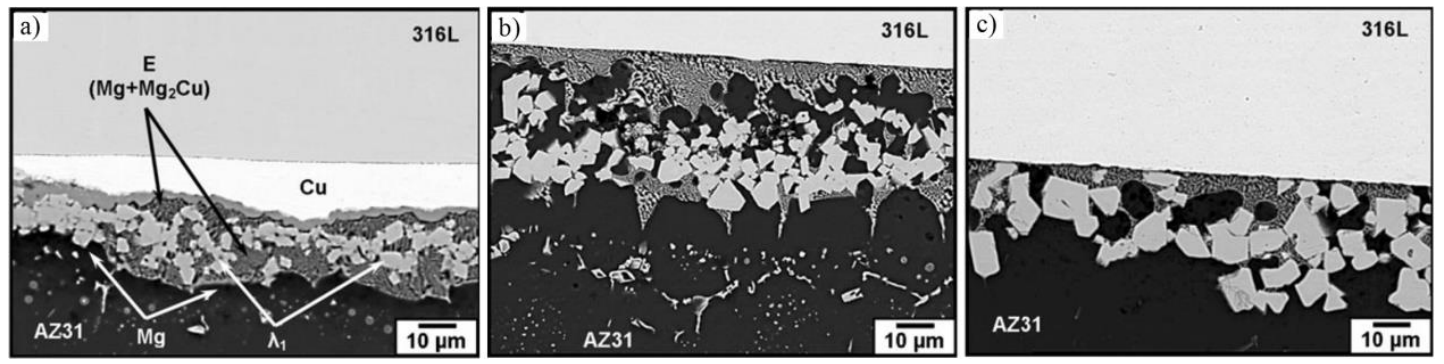

Figure 8. SEM micrographs of $\mathrm{AZ31} / \mathrm{Cu} / 316 \mathrm{~L}$ joint at $530^{\circ} \mathrm{C}$ with different bonding time [29] (a) 5 min; (b) $15 \mathrm{~min}$; (c) $30 \mathrm{~min}$.

The addition of interlayer diffusion to $\mathrm{Mg}$ alloys and steel can solve the problems of $\mathrm{Mg} /$ steel immiscibility and lack of intermetallic compounds. Diffusion bonding can control weld microstructures precisely by setting the temperature, pressure, and heating time. These researches provide a feasible way to improve the properties of joints by promoting the $\mathrm{Mg} /$ steel metallurgical bonding adding interlayer.

\section{Welding-Brazing}

Welding-brazing utilizes the difference in melting point between the two alloys, which applies a heat source to the low melting point materials (base metal or filler material). After the low melting point $\mathrm{Mg}$ alloy is melted, the high melting point steel infiltrated, and a diffusion interface layer formed at the $\mathrm{Mg}$ /steel interface. Research studies on laser welding, arc welding, and laser-tungsten inert gas (TIG) hybrid welding have been carried out on the $\mathrm{Mg}$ /steel welding-brazing joint.

\subsection{Laser Welding-Brazing}

\subsubsection{Laser Welding without Any Filler Wire or Interlayer and Coatings}

Laser self-welding only uses a laser source without filling interlayers and filler metals. In one case, the laser melted the Mg alloy, which wets and spreads on the surface of the steel, and forms a brazing joint [31-34]. In another instance, the laser was focused on the top surface of the steel plate and melted the Mg alloy by thermal conduction heat, thereby forming a brazed joint [35]. 
Firstly, laser-brazed AZ31 Mg alloy to Q235 steel joint was investigated by Miao et al. [31-33]. The Mg alloy was melted and the steel melting was restricted. The molten Mg alloy, as a filler metal, formed a successful welding brazing joint, as shown in Figure 9. A Mg/Fe transition layer was formed for the strong interfacial metallurgical reaction. The compounds were identified as Al-rich phases, such as $\mathrm{Mg}_{17} \mathrm{Al}_{12}, \mathrm{Mg}_{2} \mathrm{Al}_{3}, \mathrm{FeAl}$ and $\mathrm{Fe}_{4} \mathrm{Al}_{13}$ [33]. At the upper part of the joint, an obvious transition zone was found on the AZ31/Q235 interface, and the element distributions varied slowly in the interfacial layer, which was related to the little melting or dissolving of steel. At the lower parts, the transition zone was obscured and the elemental content changed abruptly due to the lower temperature, as shown in Figure 9e. The joint failed at the interface, and the average tensile strength of butt joints reached $185 \mathrm{MPa}$ at $0.6 \mathrm{~mm}$ laser offset [32]. Jiang et al. also adopted laser welding-brazing to join AZ31B Mg alloy and AISI304 stainless steel [34]. The maximum joint strength was $211 \mathrm{MPa}$ ( $89.8 \% \mathrm{Mg}$ base metal) with the laser offset $0.2 \mathrm{~mm}$ to $\mathrm{Mg}$ alloy side. The interface reaction layer may be composed of $\mathrm{Mg}_{17} \mathrm{Al}_{12}$ and $\mathrm{Mg}_{2} \mathrm{Ni}$ because the fracture surface at steel side detected the two IMCs.
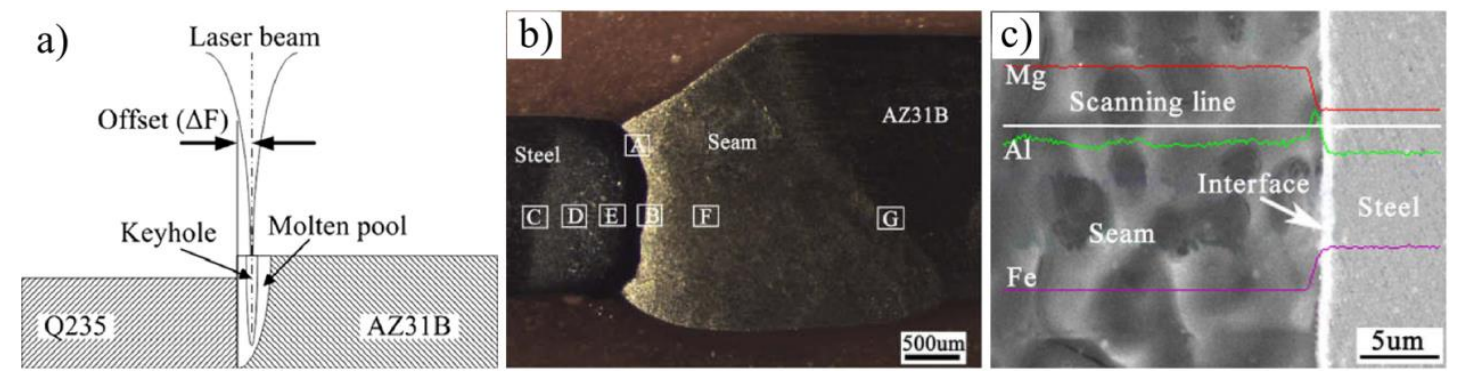

Figure 9. Laser penetration welding-brazing [32] (a) schematic diagram; (b) cross-section of butt joint;

(c) interface characteristics of the lower part of joint and element distributions.

Casalino et al. [35] put forward the laser offset to 316 stainless steel sides to bond with AZ31B/316, not using any interlayer or groove preparation, as showed in Figure 10. The joints could be bonded in the $0.3 \mathrm{~mm}$ and $0.4 \mathrm{~mm}$ offset conditions, and no bond for $0.5 \mathrm{~mm}$ offset. The ultimate tensile strength was close to $100 \mathrm{MPa}$. This technique provided a new idea that dissimilar metal welds with huge difference in physical parameters could be bonded with good tensile strength.
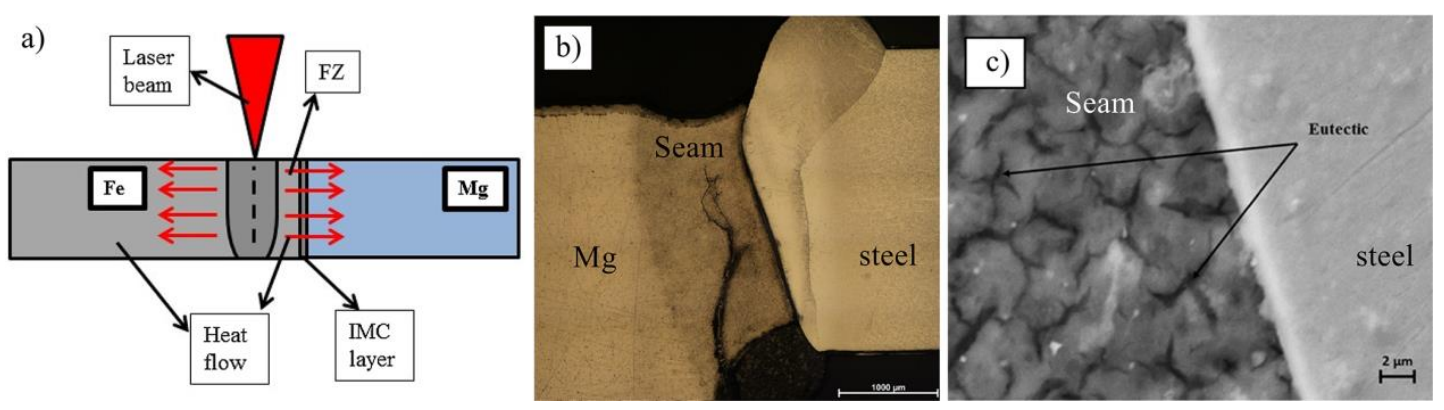

Figure 10. Laser offset welding of the AZ31/316 joint with $0.4 \mathrm{~mm}$ offset [35] (a) schematic diagram;

(b) cross section of joint; (c) the microstructure near the $\mathrm{Mg} /$ steel interface.

\subsubsection{Laser Welding with Filler Wire or Interlayer and Coatings}

On the basis of laser self-welding, the interface metallurgical bonding can be promoted by filling the welding wire to make up the burning loss problem or by adding interlayers and coatings. These filler wires, interlayers and coatings included $\mathrm{Zn}$ [7,36-40], Ni [41-43], Al [44], Sn [45], AZ31 filler wire [7,37,39,46-48], AZ92 filler wire [36,42,43,49], and others alloy elements [38,49,50].

Nasiri et al. used nickel-coated steel [42,43], Al-12Si-coated steel [49], Sn-coated steel [45], Zn-coated steel [36] with AZ92 filler wire, to carry out a series of studies by diode laser brazed AZ31B 
$\mathrm{Mg}$ to steel sheet. As shown in Figure 11, dendritic AlNi IMC and $\alpha-\mathrm{Mg}+\mathrm{Mg}_{2} \mathrm{Ni}$ phases were formed along the interface at the bottom of the joint (zone A in Figure 11b), and only a dendritic AlNi phase was generated along the interface at the middle and top side of the joint (zone $\mathrm{C}$ in Figure 11b). The shear strength of the joint reached 96.8 $\mathrm{MPa}$ [42].
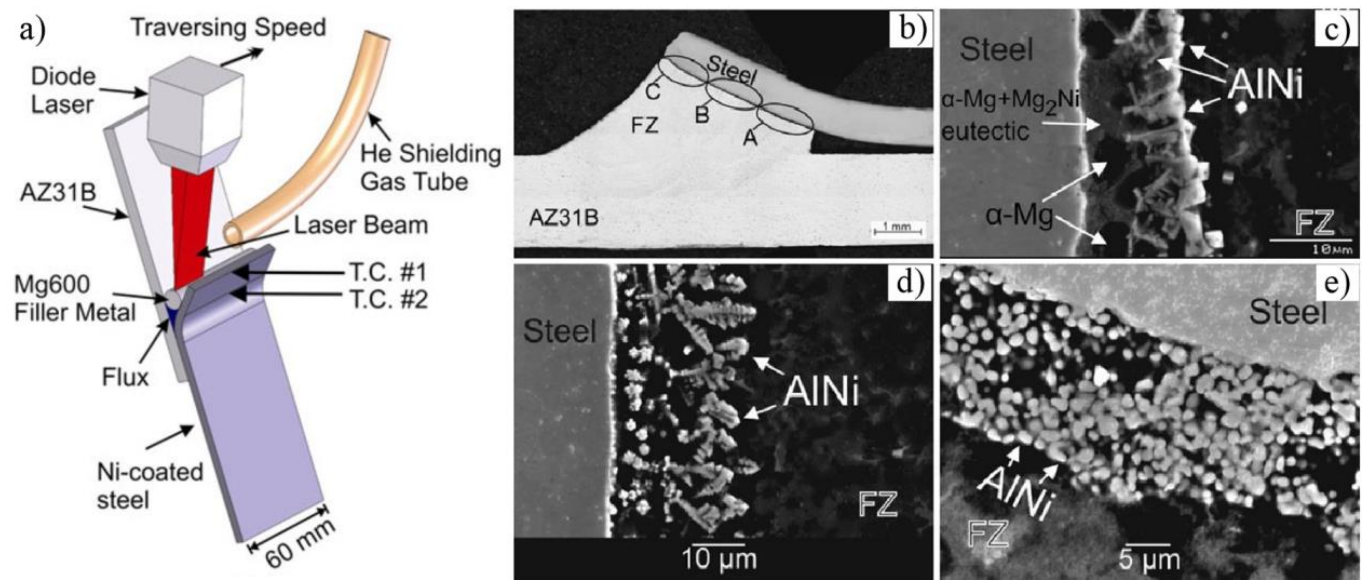

Figure 11. Laser welding of $\mathrm{Mg}$ /steel with $\mathrm{Ni}$ coating [43] (a) schematic diagram of laser bonding of AZ31 Mg and Ni electro-plated steel; (b) cross section of joint; (c-e) the microstructure of the laser-brazed specimen in A, B, C positions near the interface.

Nasiri et al. also studied the wetting characterization by measuring the contact angles of AZ92 Mg alloy on Ni-electroplated steel as a function of temperature [51], as shown in Figure 12. Reactions between molten $\mathrm{Mg}$ and $\mathrm{Ni}$ led to a contact angle of about $86 \mathrm{deg}$ in the temperature range of $891 \mathrm{~K}$ to $1023 \mathrm{~K}$ (Mode I (Mg-lNi-Mg $2 \mathrm{Ni}-\mathrm{Ni}-\mathrm{Fe})$ ), and $\mathrm{AlNi}+\mathrm{Mg}_{2} \mathrm{Ni}$ reaction products were produced between $\mathrm{Mg}$ and steel. Only $46 \mathrm{deg}$ contact angle was detected in the temperature range of $1097 \mathrm{~K}$ to $1293 \mathrm{~K}$ (Mode II (Mg-AlNi-Fe)).
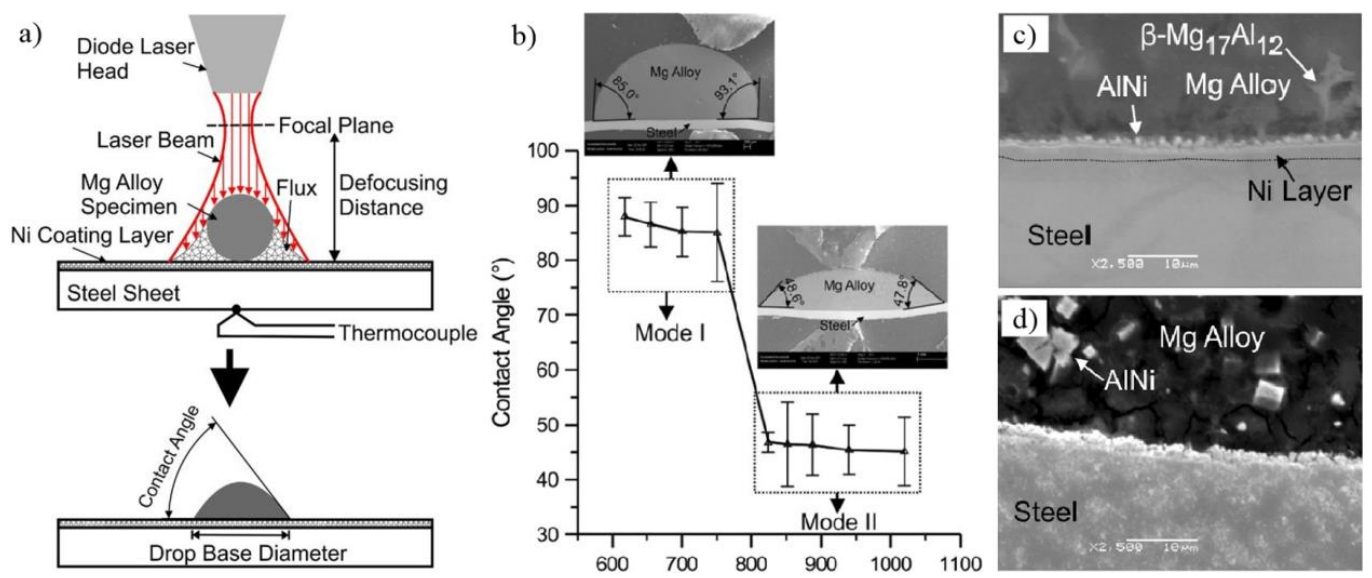

Figure 12. (a) Schematic representation of the wetting test; (b) the contact angle as a function of the peak temperature during wetting experiments; (c,d) the SEM micrographs of the Mg alloy-steel interface of the wetting sample at peak temperatures of $928 \mathrm{~K}$ and $1097 \mathrm{~K}$ [51].

The interfacial microstructure of laser brazed AZ31B Mg to Sn-plated steel was also investigated [45]. Sn coating can protect steel from oxidation and promote liquid $\mathrm{Mg}^{\prime} \mathrm{s}$ direct reaction with steel fresh surface. A nano-scale layer is formed at the $\mathrm{Mg}$ /steel interface, composed of Fe(Al) solid solution and $\mathrm{Al}_{8}(\mathrm{Mn}, \mathrm{Fe})_{5}$, as shown in Figure 13. The $\mathrm{Fe}(\mathrm{Al})-\mathrm{Al}_{8} \mathrm{Mn}_{5}$ interface showed that a crystallographic orientation relationship, $[10 \overline{1} 1]_{\mathrm{Al} 8 \mathrm{Mn} 5} / /[\overline{1} 11]_{\mathrm{Fe}(\mathrm{Al})},\{110\}_{\mathrm{Fe}(\mathrm{Al})}$ was $4.2 \mathrm{deg}$ from $\{30 \overline{3} 3\}_{\mathrm{Al}} \mathrm{Mn} 5$ with $5.2 \%$ interplanar mismatch. The $\mathrm{Al}_{8} \mathrm{Mn}_{5}-\mathrm{Mg}$ interface showed a poor crystallographic matching 
between $\mathrm{Al}_{8} \mathrm{Mn}_{5}$ and $\alpha-\mathrm{Mg}$, $[10 \overline{1} 1]_{\mathrm{Al} 8 \mathrm{Mn} 5} / /[10 \overline{1} 0]_{\mathrm{Mg}},\{30 \overline{3} 3\}_{\mathrm{Al} \text { Mn5 }}$-within 47.4 deg of the $\{0002\}_{\mathrm{Mg}}$ with $16.8 \%$ interplanar mismatch—as shown in Figure 13b,c. All specimens were fractured in the steel base metal, and interfacial tensile shear strength exhibited more than $27.5 \mathrm{MPa}$.
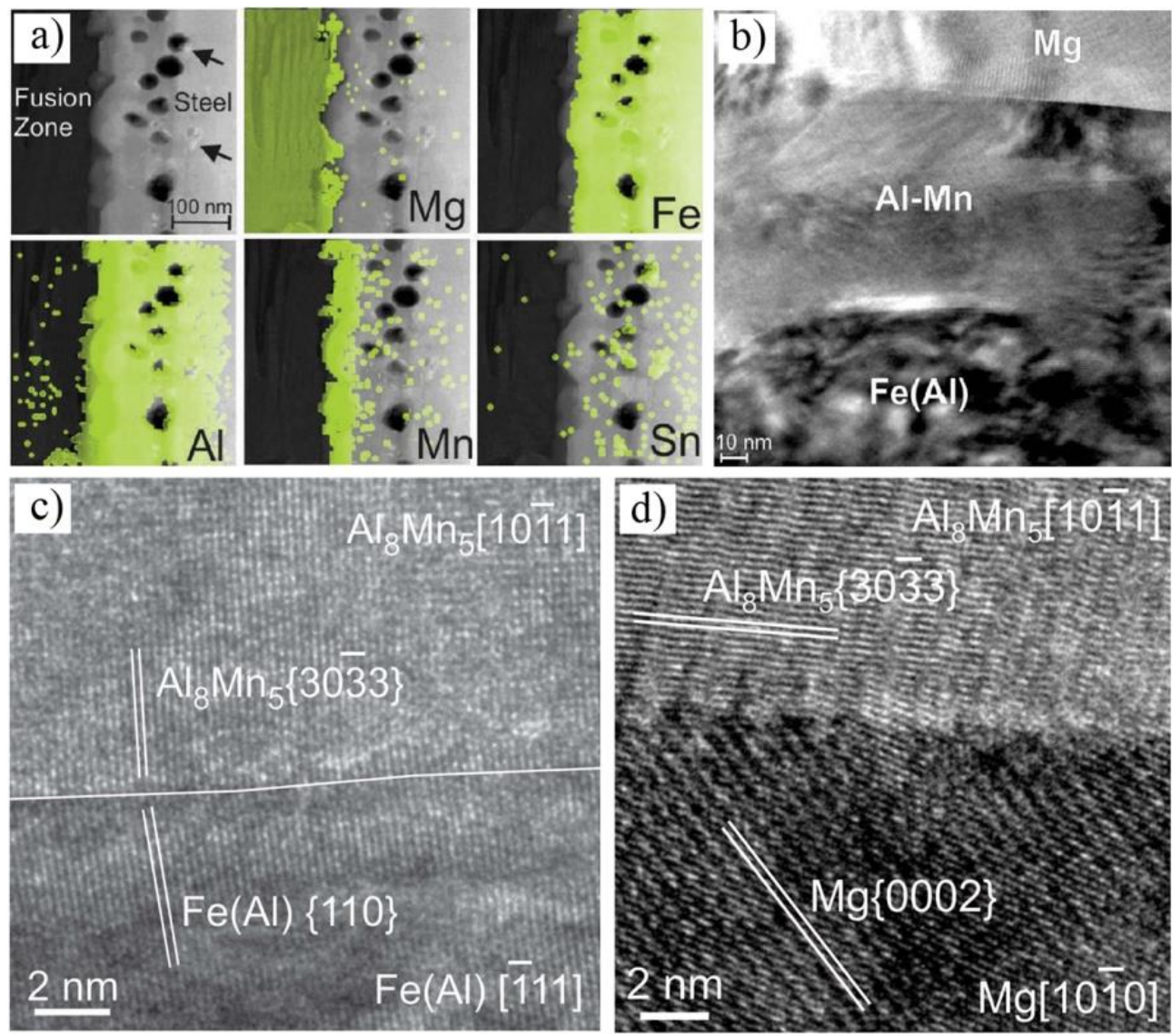

Figure 13. Laser welding of $\mathrm{Mg}$ /steel with $\mathrm{Sn}$ interlayer [45] (a) STEM-EDS concentration maps; (b) bright field TEM image of the $\mathrm{Fe}(\mathrm{Al}) / \mathrm{Al}_{8} \mathrm{Mn}_{5} / \mathrm{Mg}$ interfaces; (c,d) HR-TEM image of Fe(Al)/ $\mathrm{Al}_{8} \mathrm{Mn}_{5}$ and $\mathrm{Al}_{8} \mathrm{Mn}_{5} / \mathrm{Mg}$ interface.

Tan et al. [44] investigated the influence of $\mathrm{Al}$ interlayer thickness on laser welding of $\mathrm{Mg} / \mathrm{Steel}$, as shown in Figure 14. The interfacial metallurgical reaction was improved after the $\mathrm{Al}$ interlayer melted. Two different reaction layers were formed and distinguished between them when the thickness of the reaction layer was below $2 \mu \mathrm{m}$. $\mathrm{Fe}(\mathrm{Al})$ solid solution and $\mathrm{Al}_{8}(\mathrm{Mn}, \mathrm{Fe})_{5}$ was formed at the $\mathrm{Mg} /$ steel interface and exhibited weak strength when the thickness of reaction layer was below $2 \mu \mathrm{m}$. The reaction layer was changed to $\mathrm{Al}_{6} \mathrm{Fe}$ IMC when the reaction layer varied between $2.3 \mu \mathrm{m}$ and $5.7 \mu \mathrm{m}$, and the maximum value of the shear load reached $133 \mathrm{~N} / \mathrm{mm}(40.3 \%$ steel base metal). Cracks were detected at the $\mathrm{Mg}$ /steel interface, which resulted in the joint strength sharply reducing with increase of the thickness of the reaction layer. However, Nasiri's work indicated that the interfacial tensile shear strength could exhibit excellent performance with the composition of $\mathrm{Fe}(\mathrm{Al})$ solid solution and $\mathrm{Al}_{8}(\mathrm{Mn}, \mathrm{Fe})_{5} \mathrm{IMC}$ at the $\mathrm{Mg} /$ steel interface [45]. It might be the continuity of the $\mathrm{Al}_{8}(\mathrm{Mn}, \mathrm{Fe})_{5}$ IMC that affects the performance of the joint.

Laser welding-brazing AZ31B Mg alloy to 201 stainless steel sheet with a AZ31 Mg alloy filler wire is shown in Figure 15 [47]. The reaction layer has obvious changes with the increase of heat input, as shown in Figure 15b. The tensile test results indicate that the maximum results value was $2472 \mathrm{~N}(75.4 \% \mathrm{Mg}$ base metal) at $5.4 \mathrm{~kJ} / \mathrm{cm}$ heat input. Three different fracture modes were observed: Interfacial failure at a lower heat input, fusion zone fracture at a higher heat input, and $\mathrm{Mg}$ base metal HAZ fracture at a suitable heat input. Figure $15 \mathrm{c}$ shows a bright field image, which was taken 
at the $\mathrm{Mg} / \mathrm{steel}$ interface at $5.4 \mathrm{~kJ} / \mathrm{cm}$ heat input. A nanoscale and continuous layer was detected near the $\mathrm{Mg}$ /steel interface, which was composed of three layer: $\mathrm{Mg}_{17}(\mathrm{Al}, \mathrm{Zn})_{12}, \mathrm{Al}_{19} \mathrm{Mn}_{4}$ and $\mathrm{Fe}(\mathrm{Al})$ solid solution.

a)

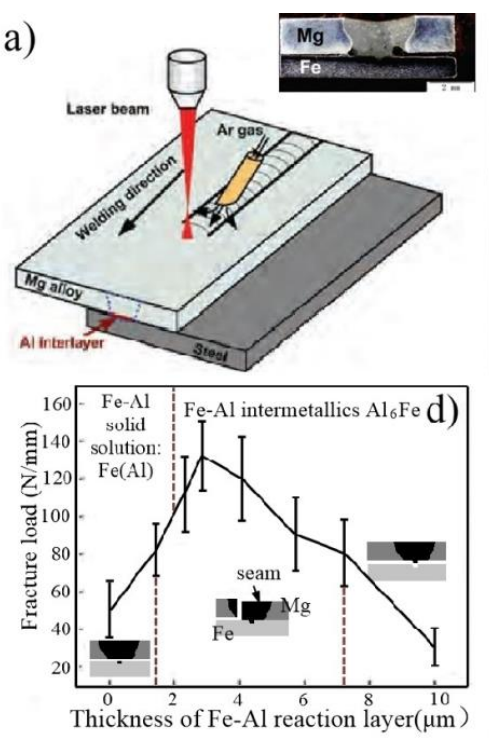

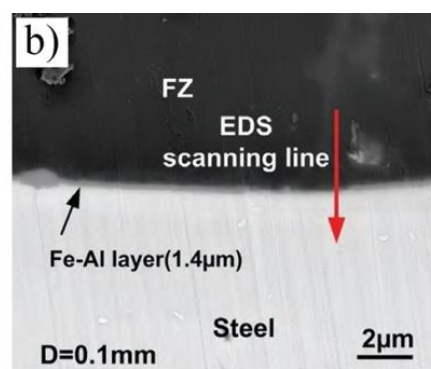

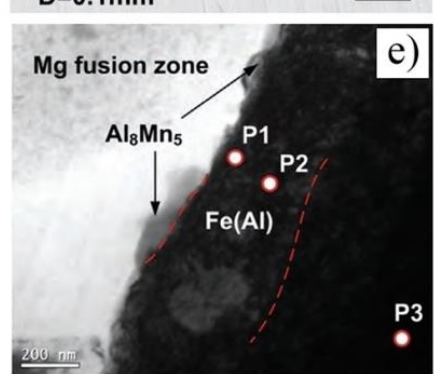

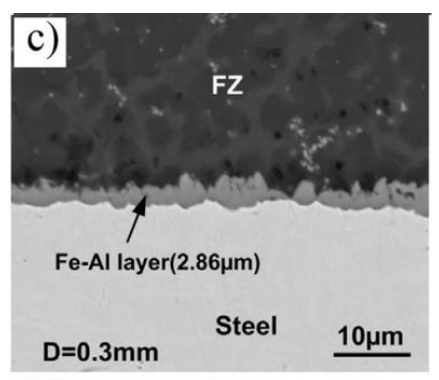

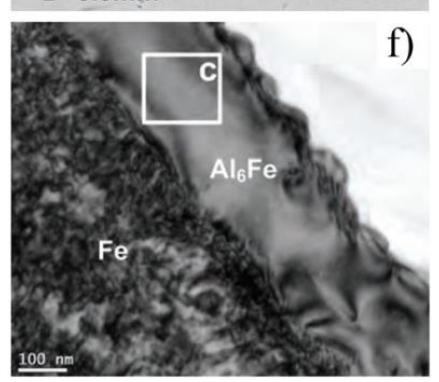

Figure 14. Laser-welding process of $\mathrm{Mg}$ to steel with the $\mathrm{Al}$ interlayer [44] (a) schematic diagram; $(\mathbf{b}, \mathbf{c})$ microstructure morphologies of interfacial reaction layers with 0.1 and $0.3 \mathrm{~mm} \mathrm{Al}$ interlayer; (d) fracture load with a function of the thickness of the reaction layer; $(\mathbf{e}, \mathbf{f})$ TEM micrograph for reaction layer below / above $2 \mu \mathrm{m}$.

a)
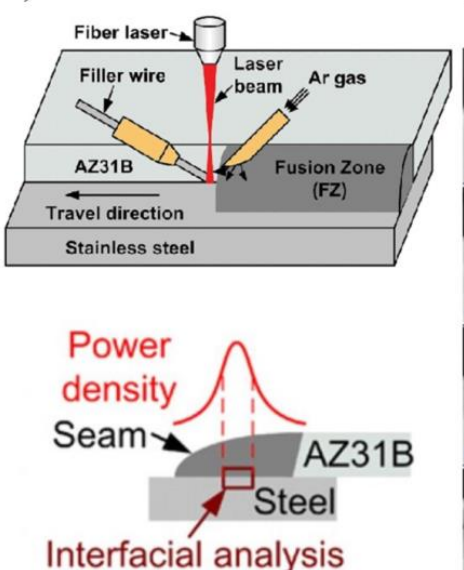

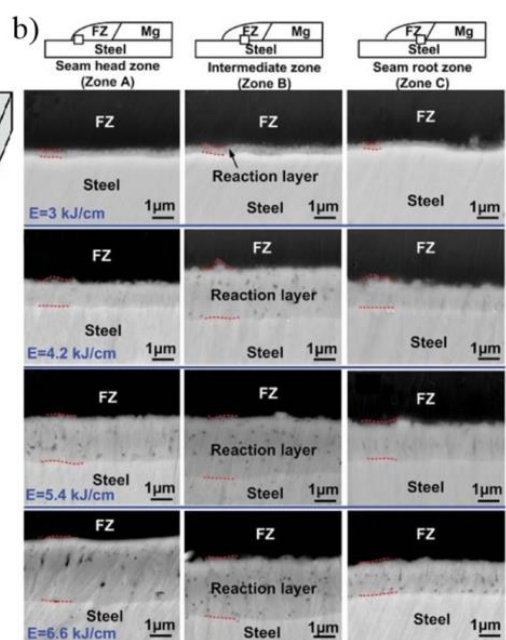

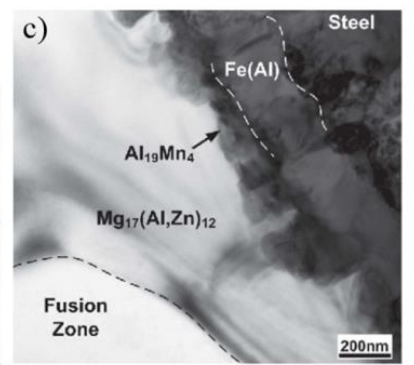

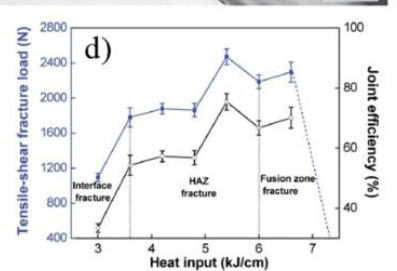

Figure 15. Laser welding-brazing with filler wire [47] (a) schematic diagram of the welding process; (b) interfacial microstructure at different heat inputs; (c) TEM bright field image at $5.4 \mathrm{~kJ} / \mathrm{cm}$ heat input; (d) tensile-shear fracture load at different heat inputs.

\subsection{Arc Welding-Brazing}

\subsubsection{Metal Inert-Gas Welding-Brazing}

The microstructure characteristics and tensile test results of AZ31 Mg/Q235 Steel dissimilar joints by MIG welding with a $\mathrm{Cu}$ interlayer are shown in Figure 16a [52,53]. The results show that the tensile strength was improved by the addition of a $\mathrm{Cu}$ interlayer, due to the improvement of wettability of $\mathrm{Mg}$ alloy on steel and the formation of eutectic structures $\left(\alpha-\mathrm{g}+\mathrm{Mg}_{2} \mathrm{Cu}\right)$ and $\mathrm{Mg}-\mathrm{Al}-\mathrm{Cu}$ ternary phases. The IMC $\mathrm{Mg}_{2} \mathrm{Cu}$ with a rod-like structure was generated in the weld zone and $\mathrm{Mg} /$ steel interfacial 
zone. The reaction layer was FeAl IMC, as shown in Figure 16f. The maximum tensile strength of joint reached $190 \mathrm{MPa}$ with $0.15 \mathrm{~mm} \mathrm{Cu}$ interlayer added (79\% $\mathrm{Mg}$ alloy base metal), and the joint failed at the fusion zone and the $\mathrm{Mg}$ /steel interface together. The effect of Al content in $\mathrm{Mg}$ alloy filler wire on the microstructure and mechanical properties of the joint was also investigated. Figure $16 \mathrm{~g}$ shows the $\mathrm{Mg}$ /steel joint, whose tensile strength could reach 184.2 MPa with the AZ31 filler metal added; its reaction layer was composed of FeAl IMC [54]. Joint strength could reach $192 \mathrm{MPa}(80 \% \mathrm{AZ31} \mathrm{Mg}$ alloy) with the AZ61 filler metal added [55].

Based on the above research, what they had in common was that the FeAl interface layer was obtained at $\mathrm{Mg}$ /steel interface and the joints exhibited better performance under the condition of adding a $\mathrm{Cu}$ interlayer or filler metal with different $\mathrm{Al}$ content. Liu et al. [56] also found that similar characteristics of joint strength with AZ31 filler metal added (171-174 MPa) was lower than the AZ61 filler metal added (201 $\mathrm{MPa}-83.8 \% \mathrm{Mg}$ alloy base metal). The $\mathrm{Mg} /$ steel interface reaction layer was composed of double-layer structures, which were $\mathrm{AlFe}_{3} \mathrm{IMC}$ layer and the $\mathrm{Mg}(\mathrm{Fe}, \mathrm{Al}) \mathrm{O}_{4}+$ $\mathrm{Mg}_{3.1} \mathrm{Al}_{0.9}$ layer.
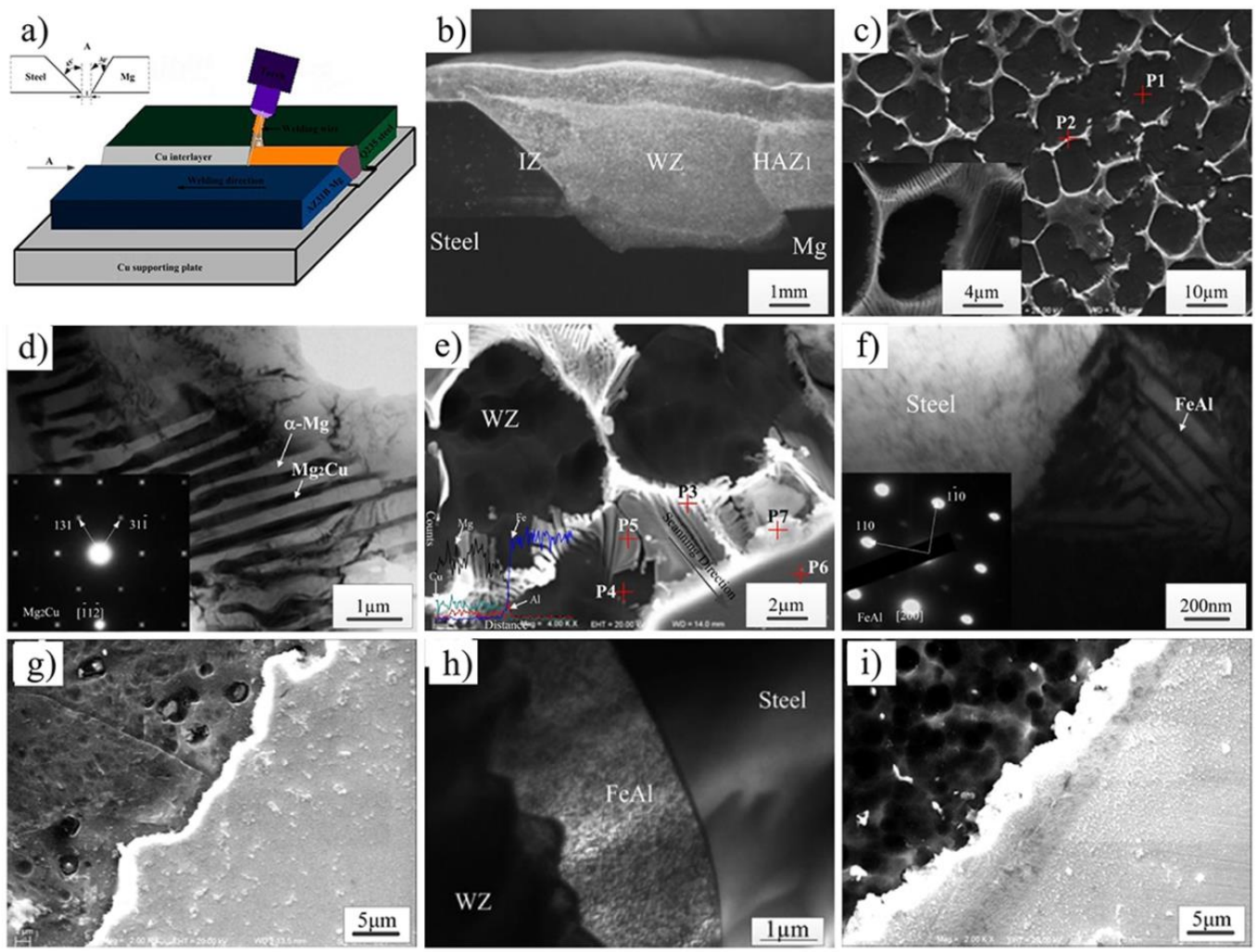

Figure 16. MIG welding process [53-55] (a) schematic diagram for Cu interlayer added; (b) cross-section of joint with $0.1 \mathrm{~mm} \mathrm{Cu}$; (c-f) microstructure of weld seam, eutectic structure, interfacial microstructure and reaction layer close to steel in (b), respectively; (g) interfacial microstructure for AZ31 filler wire added; (h) Mg/steel interface TEM image near in (g); (i) interfacial microstructure for AZ31 filler wire added.

\subsubsection{Cold Metal Transfer Welding-Brazing}

The cold metal transfer (CMT) welding process was based on common gas metal arc welding (MIG/MAG) plus the unique wire back pump technology (which allowed the wire to back pump in the event of a short circuit), reducing the heat input during welding.

Ren et al. [57] developed CMT spot joining AZ31 Mg alloy to Q235 steel with a Cu interlayer, as shown in Figure 17. There were two different bonding mechanisms at the $\mathrm{Mg} /$ steel interface: brazing at the nugget edge and welding-brazing at the center of the nugget. Composite reaction layers 
were composed of $\mathrm{Al}_{3} \mathrm{Cu}_{4} \mathrm{Fe}_{3}$ and $\mathrm{Fe}_{4} \mathrm{Cu}_{3}$ IMCs at the center of the nugget. Dissimilar $\mathrm{AZ} 31 \mathrm{Mg}$ alloy/Q235 steel joint could not be bonded by CMT spot welding without the $\mathrm{Cu}$ interlayer. The $\mathrm{Cu}$ interlayer played a bridging role in improving the weldability of $\mathrm{Mg}$ on a steel surface and promoting an interfacial metallurgical reaction.

The effects of Zn coating on $\mathrm{Mg}$ /steel lap-joints produced by the CMT method was studied $[58,59]$. The $\mathrm{Mg} /$ galvanized steel joint exhibited better spreadability and wettability than the $\mathrm{Mg} / \mathrm{bare}$ steel joint. Two interlayers $((\alpha-\mathrm{Mg}+\mathrm{MgZn}$ eutectic $)+\mathrm{Fe}-\mathrm{Al} \mathrm{IMC})$ were formed at the $\mathrm{Mg} /$ galvanized steel interface, and Fe-Al IMC was formed at the $\mathrm{Mg} /$ bare steel interface. However, the maximum tensile load of $\mathrm{Mg}$ /bare steel joint $(258 \mathrm{~N} / \mathrm{mm}$ ) was higher than that of the $\mathrm{Mg} /$ galvanized steel joint $(224 \mathrm{~N} / \mathrm{mm}$ ). For the $\mathrm{Mg} /$ galvanized steel joint and the $\mathrm{Mg} /$ bare steel joint, the welding speeds were $5 \mathrm{~mm} / \mathrm{s}$, and wire feeding speed was $7.5 \mathrm{~m} / \mathrm{min}$ and $10 \mathrm{~m} / \mathrm{min}$, respectively. The reason for the $\mathrm{Mg} /$ galvanized steel joint obtaining relatively low mechanical properties was that the bonding strength between the eutectic and the Fe-Al IMC at $\mathrm{Mg}$ /galvanized steel interface was lower than a thinner layer formed at the $\mathrm{Mg} /$ bare steel interface. Besides, CMT plug welding technology was also adopted to bond Mg AZ31 and hot-dipped galvanized mild steel, and Zn coating was the key to achieving a sound joint $[60,61]$.
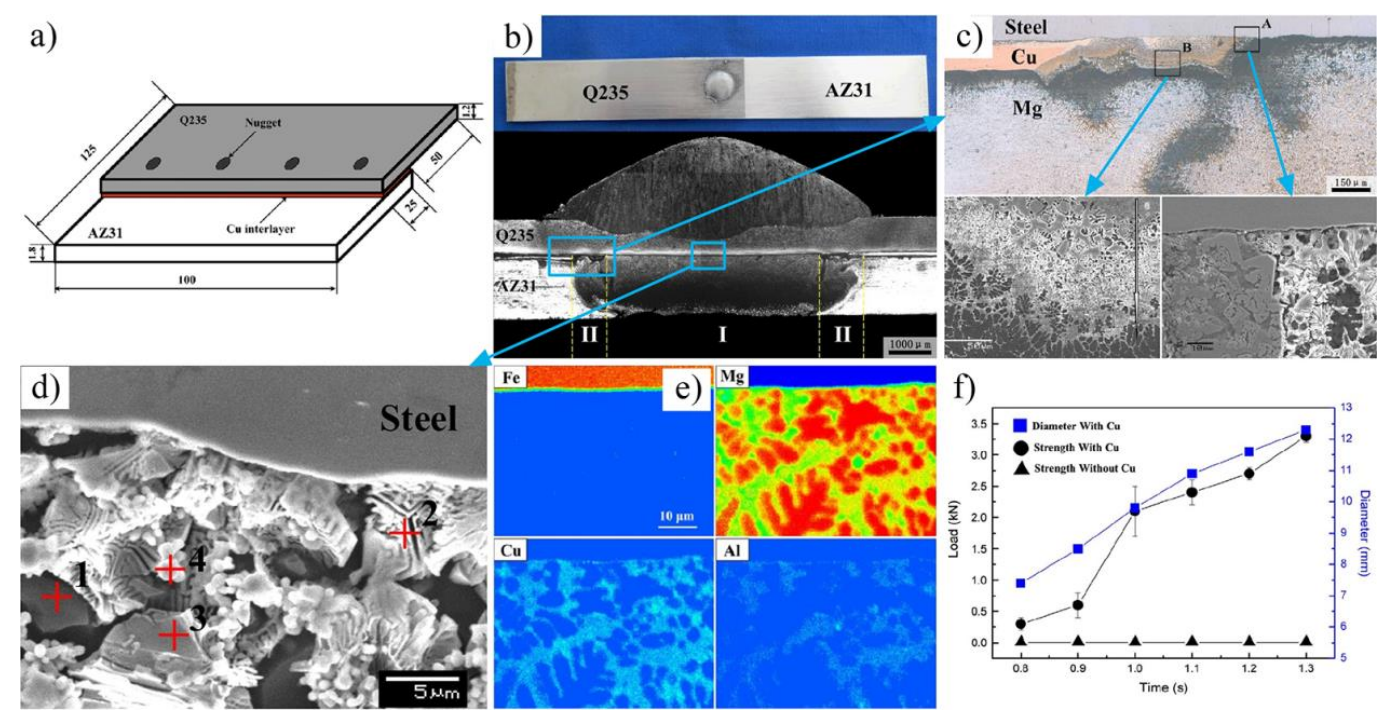

Figure 17. CMT spot welding with $\mathrm{Cu}$ interlayer [57] (a) schematic of the welding arrangement; (b) nugget surface and cross-section photograph; (c) microstructures of the interface at the nugget edge; (d) microstructures of the interface at the center of the nugget; (e) interfacial elemental distribution analysis at the center of the nugget; (f) relation between tensile shear strength and welding time.

Kang et al. also investigated the effect of four different coatings on the properties of AZ31 Mg alloy/steel joints [62]. As shown in Figure 18, different coatings on the steel surface exhibited different wettability of $\mathrm{Mg}$ on steel. Wire feed speed also played a role in wettability [63]. The wettability of AZ31-galvanized (GI) steel joint and AZ31-aluminized (Aluminized) steel joint was better than AZ31-cold rolled bare (CR) steel joint and AZ31-galva-annealed (GA) steel joint. However, the bonding strength was not in accordance with the wettability of $\mathrm{Mg}$ on steel. The AZ31-CR and Aluminized steel joint exhibited higher bonding strength because $\mathrm{Fe}-\mathrm{Al}$ phases were formed at the $\mathrm{Mg} / \mathrm{steel}$ interface. The Mg-Zn-Al ternary phase was often detected at the $\mathrm{Mg}$ /steel interface of the AZ31-GI and AZ31-GA steel joints, which restricted the improvement of the joint performance. The reaction layer that was composed of the $\mathrm{Mg}-\mathrm{Zn}$ eutectic and $\mathrm{Fe}-\mathrm{Al}$ phases exhibited poor bonding strength because of the weak bonding between the $\mathrm{Mg}$-Zn eutectic and the Fe-Al phases. In addition to the type of interface layer, the shape of the interface layer had a great influence on the mechanical properties of the joint. Chen et al. [64] found that the AZ31 Mg/Zn-coated DP600 steel spot joint strength (180 MPa) 
with a compact plate-like intermetallic $\mathrm{Al}_{2} \mathrm{Fe}$ layer was higher than the joint with an island-type $\mathrm{Al}_{2} \mathrm{Fe}$ interlayer.

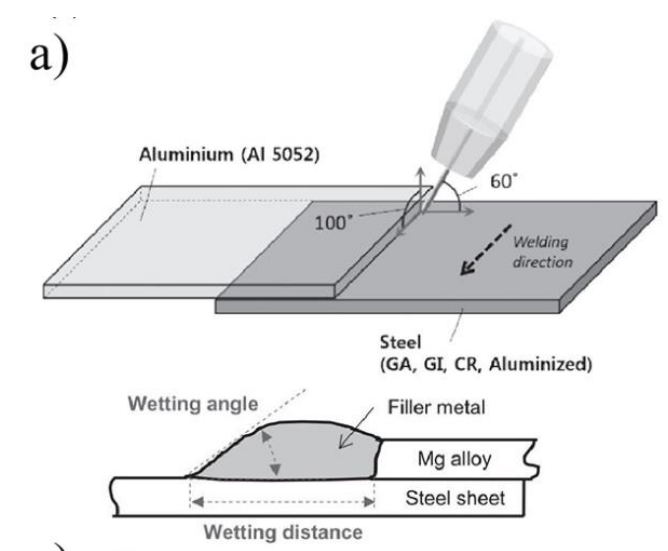

c)
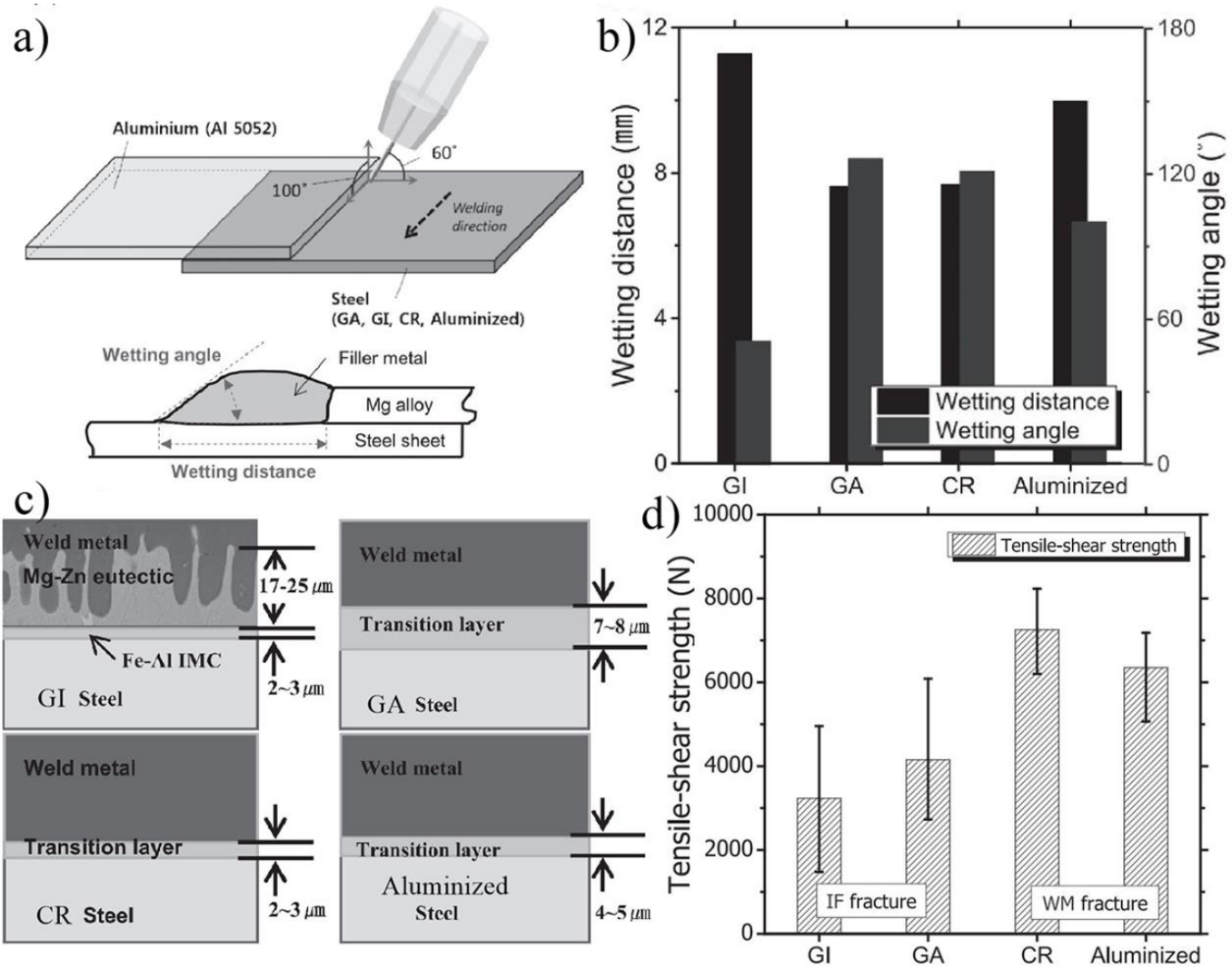

Figure 18. CMT lapped Mg-to-steel sheet welding process [62] (a) schematic diagram; (b) measured wetting angle and distance; (c) schematic of the transition layer; (d) tensile shear strength of the four types of brazed joints.

\subsection{Hybrid Heat Source Welding-Brazing}

TIG-MIG hybrid joining AZ31B Mg alloys to 430 ferritic stainless steel with a $\mathrm{Cu}$ interlayer is shown in Figure 19 [65]. The whole joint can be divided into three regions: Remaining region, full melting region, and partial melting region. The partial melting region is a major factor affecting bonding mechanism. A brazed $\mathrm{Mg}$-Cu to steel joint was formed with the $0.02 \mathrm{~mm} \mathrm{Cu}$ interlayer, and the IMCs transition layer was formed with the $0.1 \mathrm{~mm} \mathrm{Cu}$ interlayer. The maximum shear strength of the joints with added $0.02 \mathrm{~mm}$ and $0.1 \mathrm{~mm} \mathrm{Cu}$ interlayer was $57 \mathrm{MPa}$ and $84 \mathrm{MPa}$, respectively. The tensile-shear strength was improved by $47 \%$.
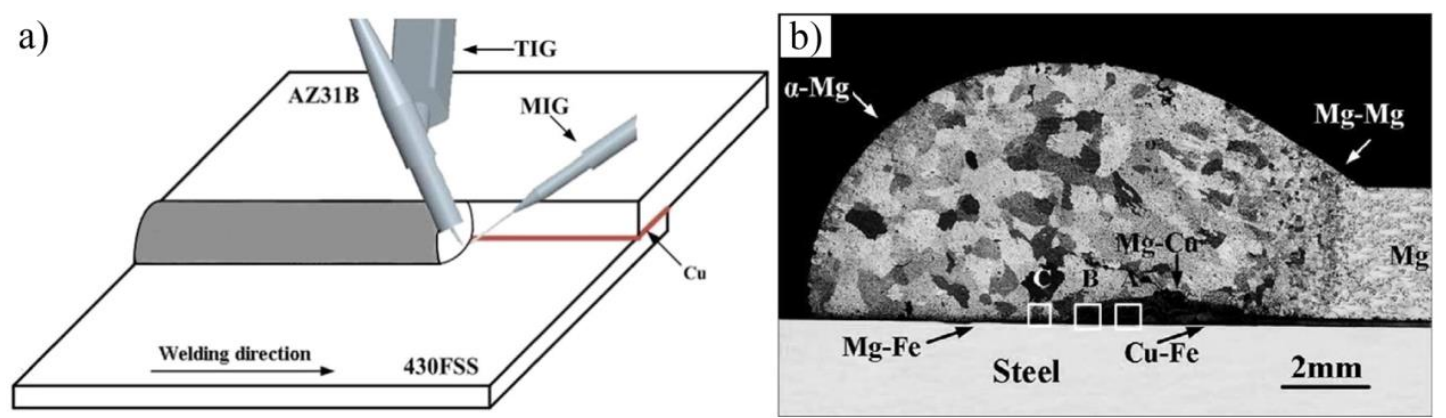

Figure 19. TIG-MIG hybrid welding with Cu interlayer [65] (a) schematic diagram; (b) cross-section photograph of the joints with $0.1 \mathrm{~mm} \mathrm{Cu}$ interlayer. 
Dissimilar metal of AZ31B Mg alloys and Zn coated DP980 steel was successfully joined by laser-TIG hybrid heat source welding-brazing [66], as showed in Figure 20a. The presence of Zn coating could prevent oxide formation at the $\mathrm{Mg}$ /steel interface. There were two bonding mechanisms: $\mathrm{Fe} / \alpha-\mathrm{Mg}+\mathrm{MgZn}$ eutectic structure $/ \mathrm{Mg}$ interfacial structure and the $\mathrm{Fe} / \mathrm{Fe}_{3} \mathrm{Al} / \mathrm{Mg}$ interfacial structure. At times, the $\mathrm{Al}_{6} \mathrm{Mn}$ phase is formed adjacent to the $\mathrm{Fe}_{3} \mathrm{Al} \mathrm{IMC}$. The maximum tensile-shear strength obtained was $68 \mathrm{MPa}(52.3 \% \mathrm{Mg}$ alloy base metal) at $1800 \mathrm{~W}$ laser power.
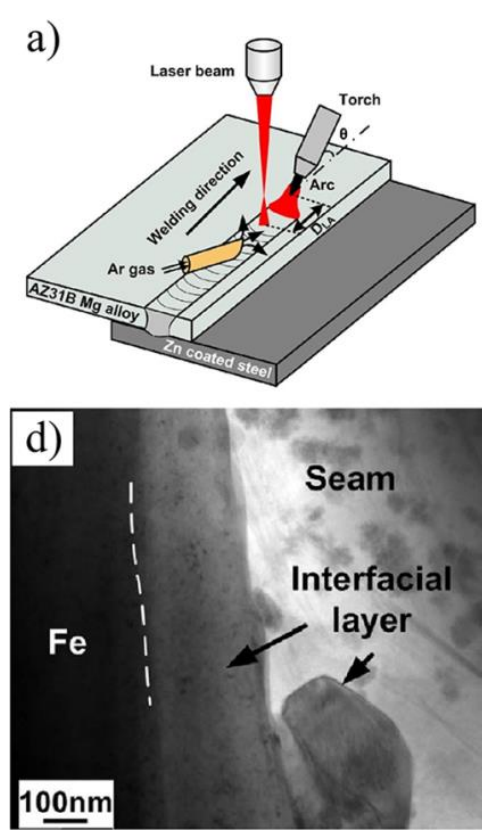
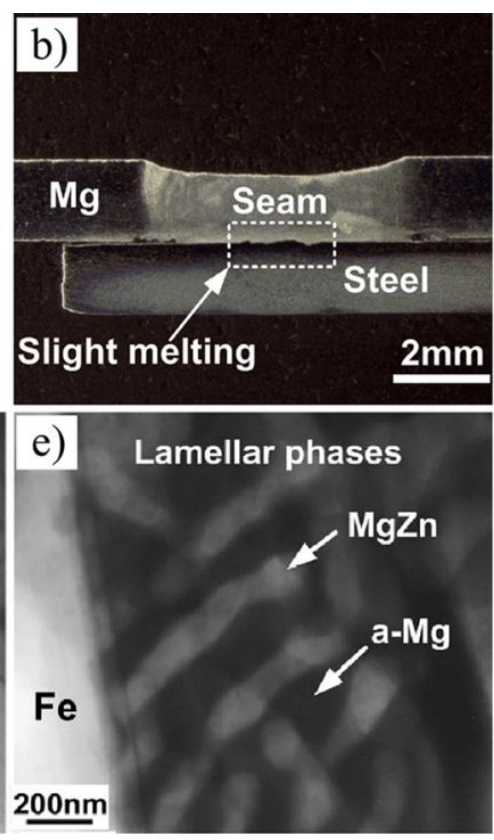
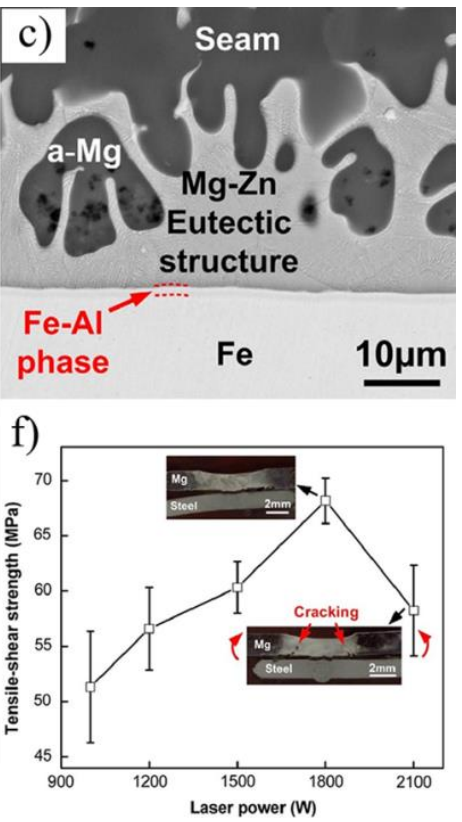

Figure 20. $\mathrm{Mg}$ /galvanized steel Laser-TIG hybrid welding process [66] (a) schematic diagram; (b) cross-section photograph; (c) interfacial microstructure morphologies at $1200 \mathrm{~W}$; (d,e) bright field micrograph taken at the interface and the seam; (f) tensile-shear strength versus laser power.

\section{Fusion Welding}

The laser-arc hybrid heat source welding technology is a new technology that combines a laser heat source and an arc heat source, thus offering the advantages of controllable energy density, high efficiency, and strong adaptability. It is now widely applied to same species and dissimilar metal welding. The fusion welding method ensures that the whole interface is always in a high temperature zone and provides a new interfacial reaction mechanism for welding of immiscible $\mathrm{Mg} / \mathrm{steel}$. This idea is completely different from that of welding-brazing and solid-state welding processes. However, there are challenges in obtaining high interfacial temperatures. The higher the interfacial temperature, the harder the welding formation is. It is impossible for Fe and $\mathrm{Mg}$ to coexist in a liquid state. As $\mathrm{Mg}$ and steel melt at the same time, Mg near the melted steel will be directly vaporized. Laser-TIG hybrid welding addresses this challenge by offering temperature gradient distribution $[67,68]$. High-energy density laser pulse can be applied to the border of $\mathrm{Mg}$ alloy and steel to increase the interfacial reaction temperature, while a low-energy density arc acts on the $\mathrm{Mg}$ alloy to reduce the burning loss, which benefits the welding formation. Existing studies show that an alloy element is the key to promoting the formation of an interface layer for immiscible $\mathrm{Mg}$ /steel joints; for instance, $\mathrm{AZ}$ series $\mathrm{Mg}$ alloy filler wire, $\mathrm{Al}, \mathrm{Ni}, \mathrm{Cu}$, and $\mathrm{Cu}-\mathrm{Zn}$ interlayer.

\subsection{Laser-Arc Hybrid Heat Source Lap Welding}

AZ31B Mg alloy and 304 steel is directly welded by laser-TIG welding in a lap joint without any interlayer or filler wire [69]. Metallic oxides produced at the $\mathrm{Mg} / \mathrm{Fe}$ interface were the reason for the poor mechanical properties of the weld joints. 
In order to minimize metallic oxides at the $\mathrm{Mg} / \mathrm{Fe}$ interface, Liu et al. conducted extensive research on laser-TIG lap fusion welding with an interlayer such as Ni [68,70-77], Cu [70-72,74,75,78], Sn [72,79], and $\mathrm{Cu}-\mathrm{Zn}[70,72]$ interlayer. The shear strength of a joint without any interlayers added was much lower than that with an interlayer. Interlayer selection should follow the principle of elevating its wettability on steel and avoiding massive production of brittle intermetallics in the joint. Morphology of different interlayer joints are shown in Figure 21. Fe-Ni solid solutions were formed close to steel and $\mathrm{Mg}_{2} \mathrm{Ni}$ IMC close to the $\mathrm{Mg}$ alloy with an Ni interlayer added. $\mathrm{Mg}_{2} \mathrm{Cu}$ IMC with rod-like structures in the joint and an equiaxed structure at the interface were found with a $\mathrm{Cu}$ interlayer added. $\mathrm{Mg}_{2} \mathrm{Sn}$ IMC with a dendritic structure distributed was identified in the grain boundaries of the $\mathrm{Mg}$ alloy with an Sn interlayer added [79]. A comparison of the tensile-shear properties of joints with different interlayers can be seen in Figure 21b.

a)
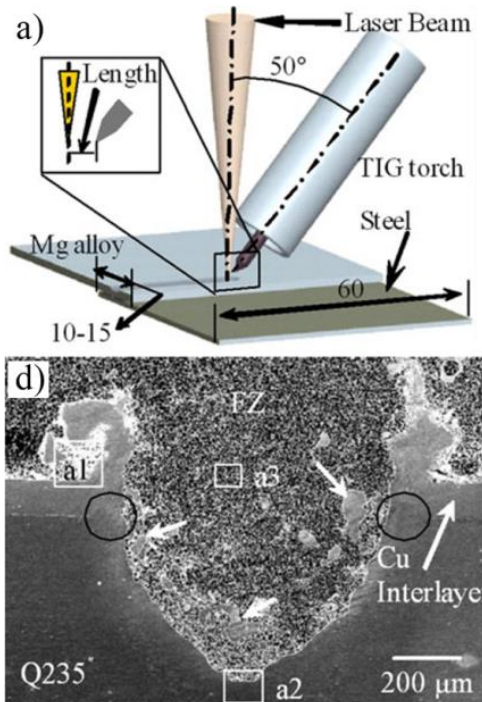
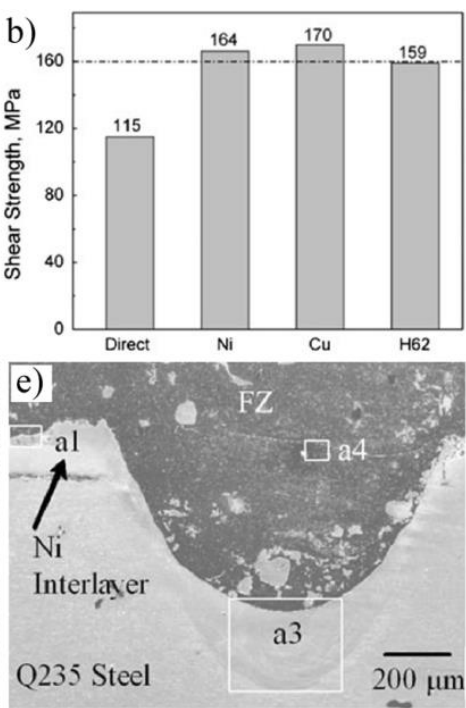
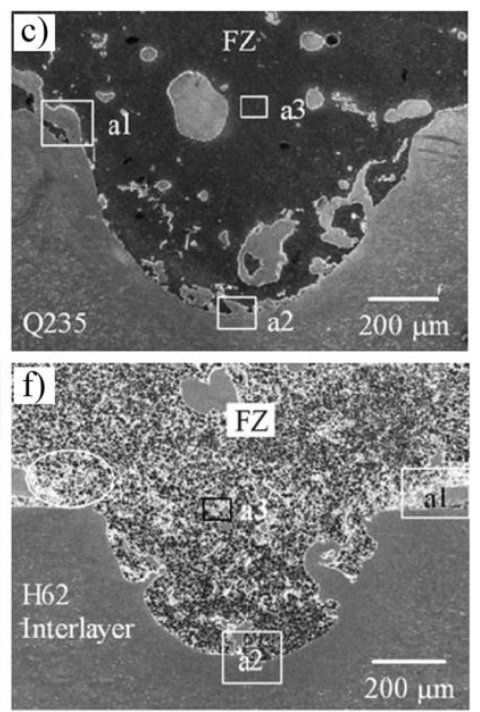

Figure 21. Laser-TIG lap welding with different interlayers [70] (a) schematic diagram of welding; (b) strength comparison of various interlayer-added joints; (c-f) microstructures of $\mathrm{Mg}$ /steel joints with no $\mathrm{Cu}, \mathrm{Ni}, \mathrm{Cu}-\mathrm{Zn}$ interlayer.

\subsection{Laser-Arc Hybrid Heat Source Butt Welding}

The effect of gradient thermal distribution on the microstructure and property of an $\mathrm{Mg} / \mathrm{steel}$ butt joint was investigated [67]. The maximum tensile strength value was $203 \mathrm{MPa}$ with laser offset to steel $0.2 \mathrm{~mm}$. Interfacial metallurgical reaction occurred at the $\mathrm{Mg} /$ steel interface alloy and formed a $\mathrm{Cu}-\mathrm{Mg}-\mathrm{Zn} \mathrm{IMC}$ and Fe-based (Fe, $\mathrm{Cu}, \mathrm{Al}$ ) solid solution. Besides, the Ni interlayer was also adopted to bond to an unequal thickness $\mathrm{Mg}$ /steel butt-welded plate [80,81], as shown in Figure 22. Laser-TIG double-sided welding was adopted to melt the Ni interlayer, which required more heat input than with a $\mathrm{Cu}-\mathrm{Zn}$ interlayer. Uniformly distributed fine particles (AlNi) were formed in the fusion zone, which was conducive to improving weld strength. The maximum tensile strength value was $232 \mathrm{MPa}$ with laser offset to steel $0.1 \mathrm{~mm}$. The transition zone between the weld seam and the steel base metal was composed of (Al, Mg) (Ni, Mn, Fe) intermetallic-based solid solutions (150 nm thickness) and $\alpha-(\mathrm{Fe}, \mathrm{Ni})$ solid solution $\left(60-500 \mu \mathrm{m}\right.$ thickness). The interplanar of $(110)_{(\mathrm{Al}, \mathrm{Mg})(\mathrm{Ni}, \mathrm{Mn}, \mathrm{Fe})} \|(0002)_{\mathrm{Mg}}$ and interatomic of $[\overline{1} 11](\mathrm{Al}, \mathrm{Mg})(\mathrm{Ni}, \mathrm{Mn}, \mathrm{Fe})$ and $[11 \overline{2} 0]_{\mathrm{Mg}}$ misfits for the $(\mathrm{Al}, \mathrm{Mg})(\mathrm{Ni}, \mathrm{Mn}, \mathrm{Fe}) / \mathrm{Mg}$ system were reduced by $42.2 \%$ and $41.2 \%$.

The AZ61 filler wire was also used in butt fusion welding of AZ31B Mg alloy and Q235 steel [82,83]. A reaction layer is formed at the welding interface enriched with $\mathrm{Al}$ and Mn elements, as shown in Figure 23. The morphology of $\mathrm{Mg}$ /steel joint and thickness of the transition layer were the key factors influencing the properties and fracture behavior of the welded joint. The $\mathrm{Mg} / \mathrm{steel}$ interface layer was composed of $\mathrm{HT}-\mathrm{Al}_{11}(\mathrm{Mn}, \mathrm{Fe})_{4} \mathrm{IMC}(50 \mathrm{~nm}$ thickness) and $\alpha-\mathrm{Fe}(\mathrm{Al})$ solid solution $(350 \mathrm{~nm}$ 
thickness). The misfit was $2.69 \%$ along $(011)_{\alpha}{ }^{-} \mathrm{Fe}(\mathrm{Al}) \|(060)_{\mathrm{HT}^{-}} \mathrm{Al11}(\mathrm{Mn}, \mathrm{Fe}) 4$ planes and $1.67 \%$ along $[1 \overline{10}]_{\alpha}{ }^{-} \mathrm{Fe}(\mathrm{Al}) \|[100]_{\mathrm{HT}^{-}} \mathrm{Al11}(\mathrm{Mn}, \mathrm{Fe}) 4$ directions with theoretical calculations. The misfit was $3.50 \%$ along $(01 \overline{1} 2)_{\mathrm{Mg}} \|(060)_{\mathrm{HT}^{-}} \mathrm{Al11}(\mathrm{Mn}, \mathrm{Fe}) 4$ planes and $17.68 \%$ along $[10 \overline{1} 0]_{\mathrm{Mg}} \|[100]_{\mathrm{HT}^{-}} \mathrm{Al11}(\mathrm{Mn}, \mathrm{Fe}) 4$ directions with theoretical calculations. The tensile strength reached $238.1 \mathrm{MPa}(94.5 \%$ of AZ31 base metal) with the weld reinforcement removed, and the joint failure approach at the $\mathrm{Mg} /$ steel interface.
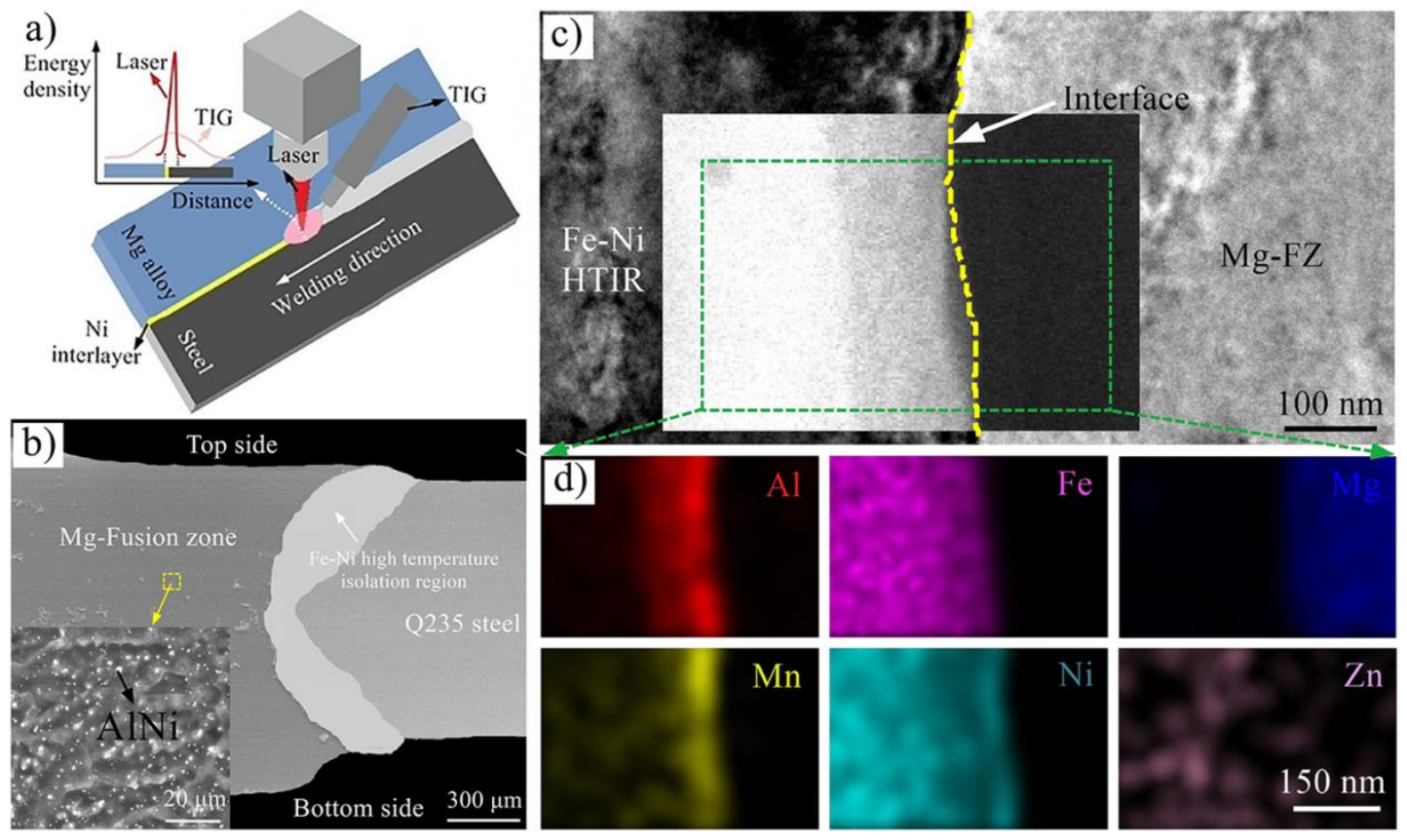

Figure 22. Laser-TIG double side welding process with Ni interlayer [81] (a) schematic representation of the laser-TIG process; (b) Cross section of joint; (c) TEM bright field image and HAADF-STEM image near the interface; (d) elemental distribution mapped with STEM near the interface marked in (c).
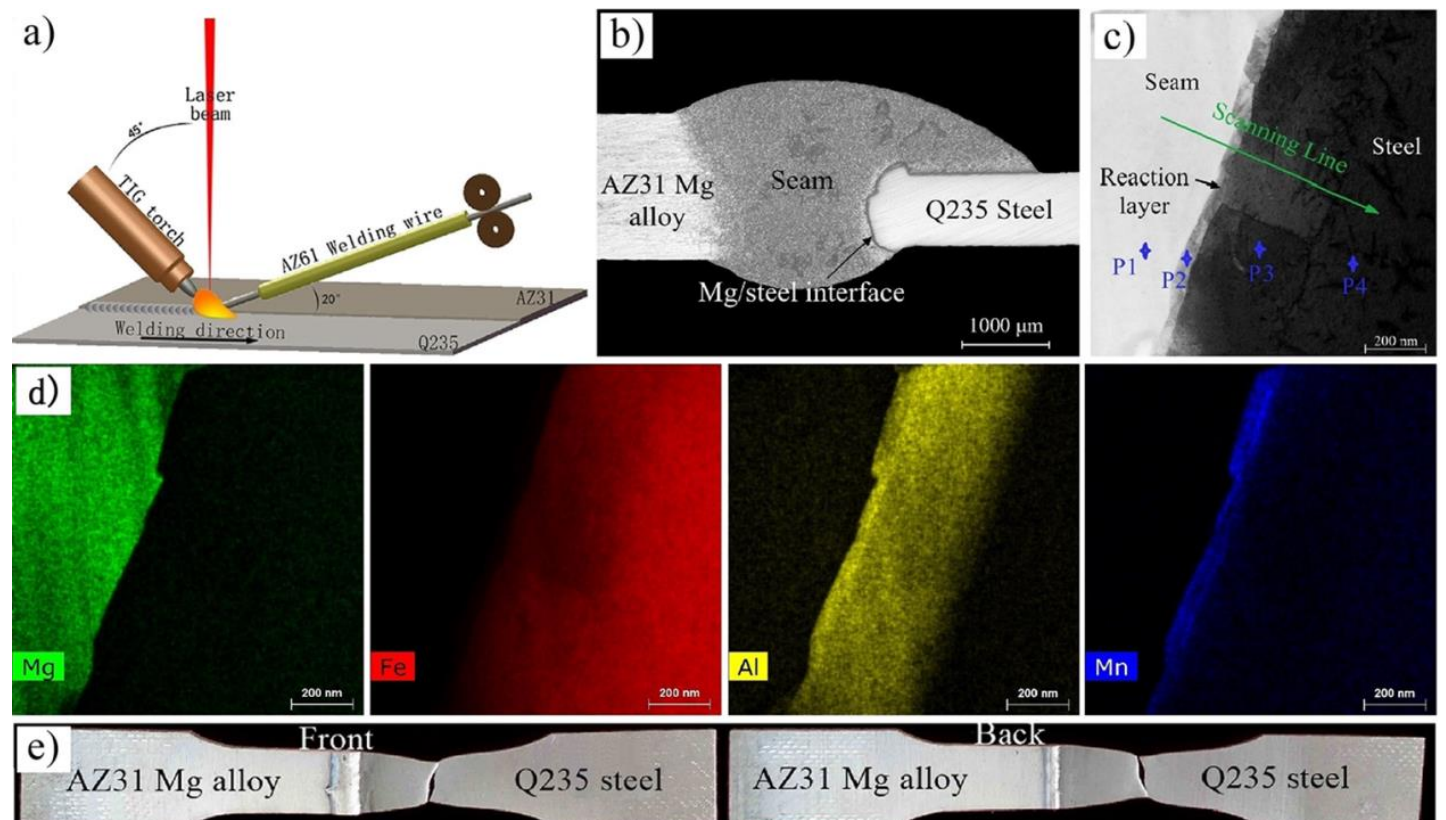

AZ31 Mg alloy
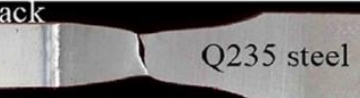

Figure 23. Laser-TIG hybrid welding with filler wire [83] (a) schematic diagram of welding; (b) cross-section appearance for $850 \mathrm{~W}$; (c) STEM micrograph taken from the interface of $\mathrm{Mg}$ /steel joint; (d) elemental distribution of $\mathrm{Mg}$, Fe, $\mathrm{Al}, \mathrm{Mn}$; (e) fracture location of joint. 


\section{Other Processes}

\subsection{Resistance Spot Welding}

In resistance spot welding (RSW), a joint is welded under a certain pressure and current. When resistance heat is generated and applied to the interface of the workpiece, the materials are bonded.

Dissimilar metals of AZ31B Mg alloy and steel joints were successfully bonded by RSW [84-90], as shown in Figure 24. Liu et al. found that a precoated nanoscale $\mathrm{Fe}_{2} \mathrm{Al}_{5}$ transition layer matched well with $\mathrm{Mg}$ and steel lattices, and could help obtain a sound joint [89]. This is because well-matching lattice sites have low-energy interfaces, which boost the interface bonding strength. The study found that $\mathrm{Fe}_{2} \mathrm{Al}_{5}$ and Fe matched well with the OR of $(002)_{\mathrm{Fe} 2 \mathrm{Al} 5} \|(110)_{\mathrm{Fe}}$ planes and $[1 \overline{1} 0]_{\mathrm{Fe} 2 \mathrm{Al} 5} \|[1 \overline{1} 1]_{\mathrm{Fe}}$ direction, $\mathrm{Fe}_{2} \mathrm{Al}_{5}$ and $\mathrm{Mg}$ matched well with the $\mathrm{OR}$ of $(002)_{\mathrm{Fe} 2 \mathrm{Al} 5} \|(01 \overline{12})_{\mathrm{Mg}}$ planes and $[010]_{\mathrm{Fe} 2 \mathrm{Al5}} \|[100]_{\mathrm{Fe}}$ direction. Besides, they also found that an interfacial intermetallic transition layer was not the only measure of successful bonding of dissimilar $\mathrm{Mg}$ /steel metals. A Mg nano grain layer could also bond immiscible pure Mg-Fe dissimilar materials [87]. However, the weld strength of AZ31/DP600 joint $(5.7 \mathrm{kN})$ with an $\mathrm{Fe}_{3} \mathrm{Al}$ interfacial layer was higher than a pure $\mathrm{Mg} / \mathrm{Fe}$ joint $(2.08 \mathrm{kN})$.

a)
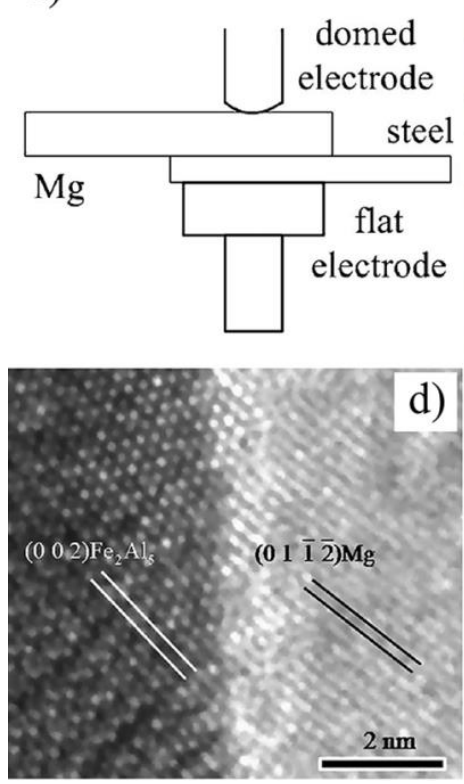
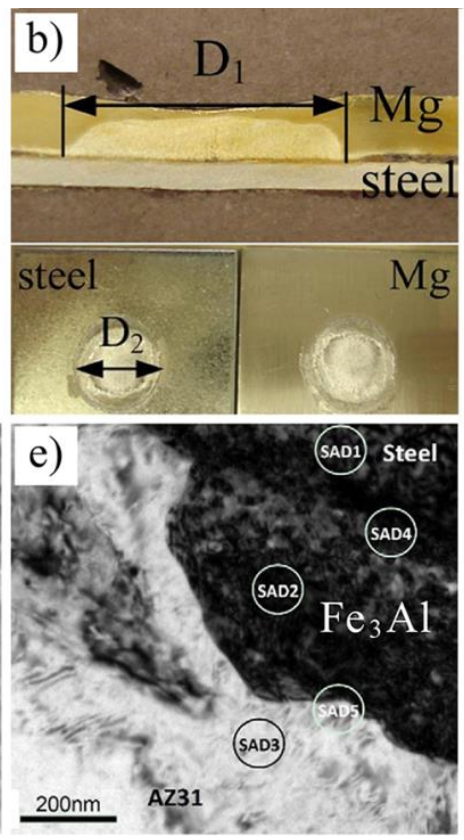
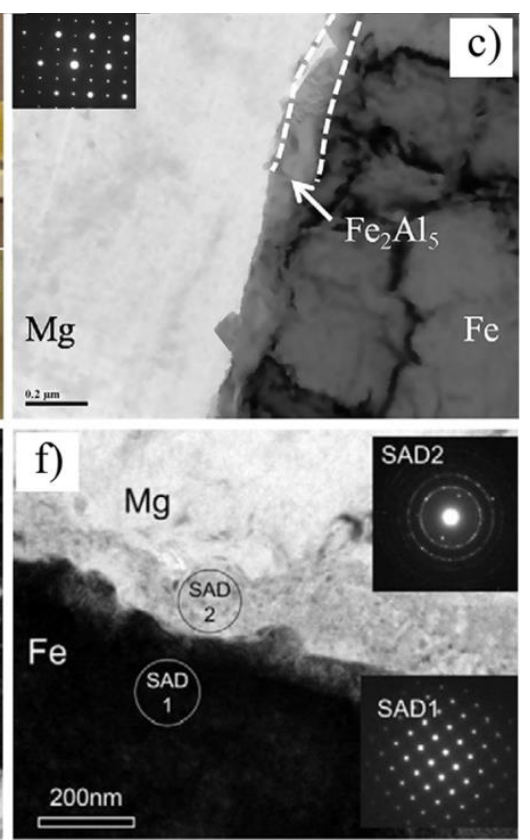

Figure 24. $\mathrm{Mg}$ /steel RSW process $[87,89,90]$ (a) schematic diagram; (b) cross section of weld and fracture surface; (c) $\mathrm{Mg} / \mathrm{Fe}_{2} \mathrm{Al}_{5} / \mathrm{Fe}$ interface structure; (d) HRTEM of $\mathrm{Fe}_{2} \mathrm{Al}_{5}$ and $\mathrm{Mg}$; (e) bright field image of the interface IMC layer of AZ31/DP600 steel joint; (f) high magnification image of the Mg/IF steel interface.

Besides resistance element welding (REW) [84], RSW with a hot-dip galvanized Q235 steel interlayer [85] and RSW with a cover plate [86] were also adopted to bond Mg/steel dissimilar metals. As shown in Figure 25a, only a nugget was formed in the Mg alloy, which had a welding-brazing character for the AZ31 Mg alloy/316 L austenitic stainless steel joint. Two nuggets were formed during REW (Figure 25b): One near the Q235/316 L interface and the other in the Mg alloy close to the $\mathrm{Mg} / \mathrm{Q} 235$ interface [84]. The peak load of the REW joints was $3.71 \mathrm{kN}$, which was higher than that of RSW joints $(2.23 \mathrm{kN})$. Similarly, a high quality AZ31/DP600 joint was obtained by RSW with a hot-dip galvanized Q235 steel interlayer [85], as shown in Figure 25c. The maximum peak load (5.49 kN) was increased by $32.6 \%$, when compared to a traditional RSW joint $(4.14 \mathrm{kN})$. 
AZ31B Mg alloy/hot-dip galvanized HSLA steel dissimilar metals were successfully welded by resistance spot welding [88]. The fatigue performance of $\mathrm{Mg}$ /steel welds was almost the same as that of $\mathrm{Mg} / \mathrm{Mg}$ welds, as shown in Figure 26. $\mathrm{Mg}$ /steel and $\mathrm{Mg} / \mathrm{Mg}$ welds were fractured in the thickness direction of $\mathrm{Mg}$ alloy under stress-controlled cyclic loading. Zinc coating enters the molten pool to prevent liquid metal embrittlement, which results in fatigue fracture appearing in the thickness direction of the $\mathrm{Mg}$ alloy.
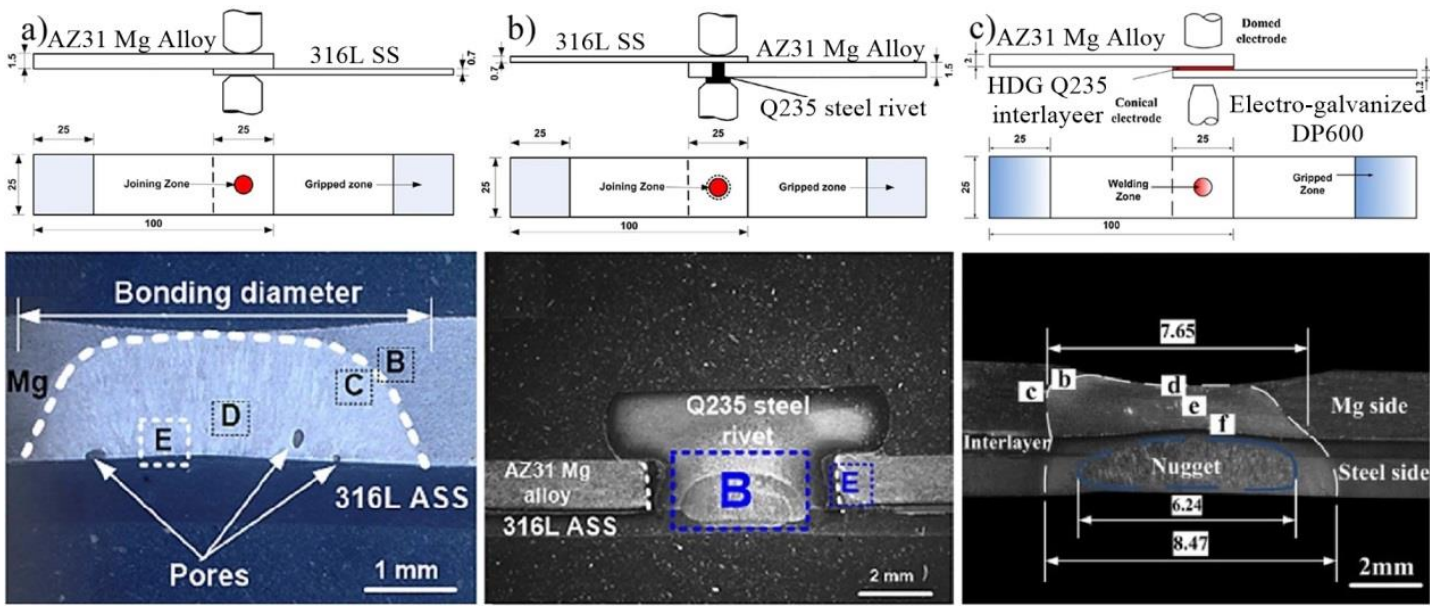

Figure 25. Mg/steel RSW process $[84,85]$ (a) schematic diagram of the traditional RSW process and cross-section of the weld; (b) schematic diagram of the REW process and cross-section of the weld; (c) schematic diagram of RSW with Q235 interlayer process and cross-section of the weld.
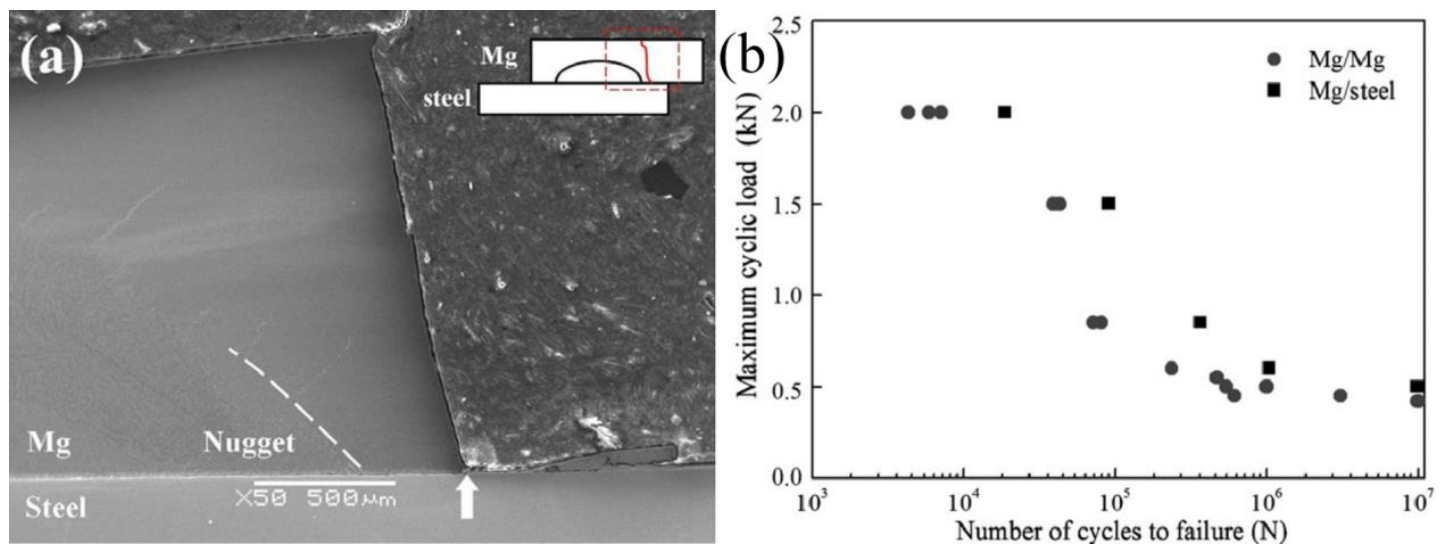

Figure 26. Mg/steel RSW [88] (a) fatigue fractures at a maximum load of $2.0 \mathrm{kN}$; (b) fatigue properties.

\subsection{Ultrasonic Spot Welding}

$\mathrm{Mg}$ /steel dissimilar metals such as Mg-to-galvanized steel [91-95], Mg-to-bare steel with Sn interlayer [91,96], and Mg-to-galvanized steel with adhesives [97,98] were successfully bonded by ultrasonic spot welding (USW). The effects of different steel surface coatings on the microstructure and properties of USW Mg/steel joints are shown in Figure 27 [91]. Weak interface bonding strength was obtained for USW Mg-to-bare steel. For Mg-to-bare steel with a Sn interlayer joint, the transition layer was composed of Sn and a $\mathrm{Mg}_{2} \mathrm{Sn}$ eutectic structure [91,96]. $\mathrm{Mg}_{7} \mathrm{Zn}_{3}$ and $\mathrm{Mg}_{2} \mathrm{Zn}_{11}$ were presented in the interface of the Mg-to-galvanized steel joint [91], and sometimes detected as $\mathrm{MgZn}_{2} \mathrm{IMC}$ together [92]. The shear strength of the $\mathrm{Mg} / \mathrm{Sn}$ coated steel joint $(71 \mathrm{MPa})$ was higher for $\mathrm{Mg} / \mathrm{bare}$ steel (samples failed during mounting of the lap shear test) and $\mathrm{Mg} / \mathrm{Zn}$ coated steel joint (56 MPa). 

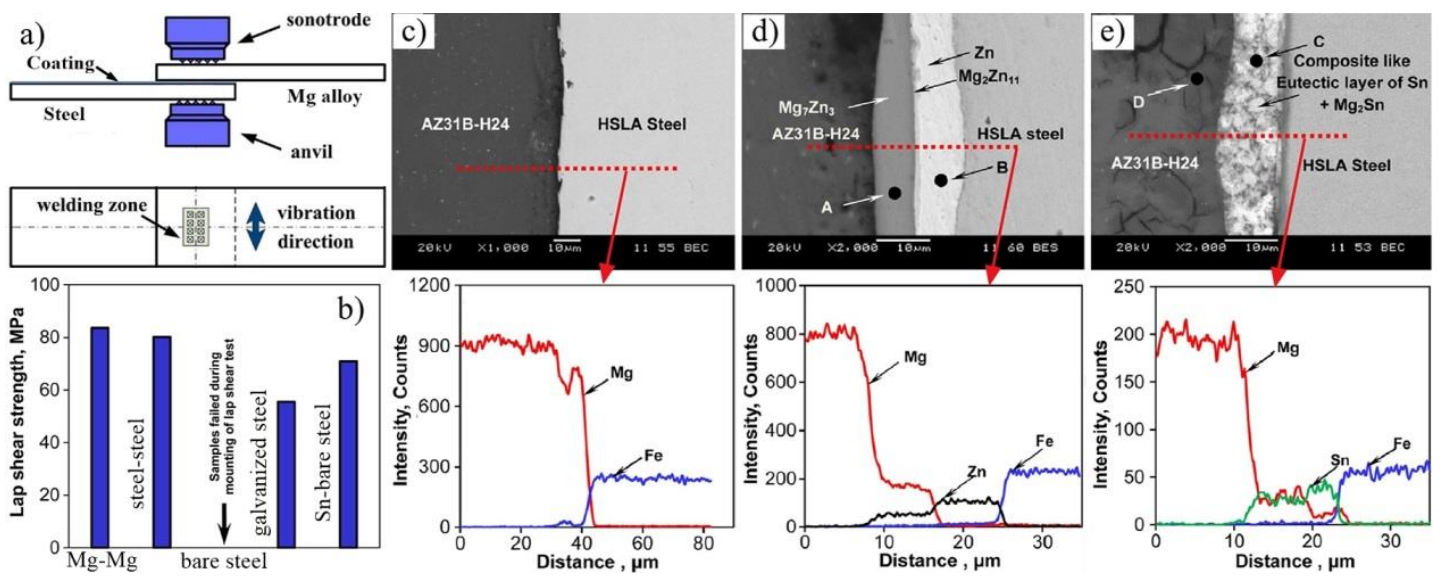

Figure 27. Mg/steel USW process [91] (a) schematic diagram of USW process; (b) Lap shear strength for different coated steel; (c) Mg-to-bare steel; (d) Mg-to-galvanized steel and (e) Mg-to-bare steel with Sn interlayer

\section{Summary}

$\mathrm{An} \mathrm{Mg}$ /steel dissimilar metal hybrid welding structure has both strength requirements and light weight advantages, and offers broad application prospects for the future. Therefore, scholars have been using different welding techniques to carry out systematic research. The key issues for $\mathrm{Mg}$ /steel dissimilar metal joints are the large difference in melting point, no $\mathrm{Mg}$-Fe IMCs, and little solid solubility in an Mg-Fe system.

Solid-phase welding (friction stir welding and diffusion welding) can effectively solve the problem of large differences in melting points of $\mathrm{Mg}$ /steel dissimilar metals and avoid welding defects in fusion welding. In order to promote the metallurgical bonding interface of $\mathrm{Mg}$ and steel, a large number of scholars have adopted the welding-brazing method. A heat source is applied to the Mg alloy (base metal or filler material), melting the $\mathrm{Mg}$ alloy by utilizing the difference in melting point between the $\mathrm{Mg}$ alloy and steel. The use of a cladding metal or an interlayer metal could effectively promote infiltration of the alloy elements into the solid steel base metal, and achieve a metallurgical bonding interface during welding-brazing, such as laser welding-brazing, arc welding-brazing, and hybrid heat source welding-brazing. Besides, $\mathrm{Mg}$ /steel fusion welding is also a promising technique that could promote interfacial metallurgical reactions and obtain more stable intermetallic compounds (IMC). The laser-TIG hybrid welding technique is a typical method that deals with the issue of large differences in melting and boil points between $\mathrm{Mg}$ and Fe. The high-energy density laser could increase interfacial temperature and promote interfacial reaction, and the low energy density arc could reduce evaporation of the $\mathrm{Mg}$ alloy.

Although the bonding of $\mathrm{Mg}$ alloy and steel has made great progress, there are several problems that need to be solved. The key factors that affect the performance of the joint are the thickness, continuity, and type of the interface layer. Few studies have focused on the design of the interface layer type, and the effect of different types of interface layers on the bonding of $\mathrm{Mg} /$ steel dissimilar metals. The $\mathrm{Mg}$ /steel interface bonding mechanism is still not clear. Although an edge-to-edge matching model was used to predict orientation relationships (OR) of $\mathrm{Mg} / \mathrm{IMC}$ and IMC/steel and characterize bonding strength of interfaces, there are not enough matching theories to compare the interface strengthening mechanism of different interface layers. There are others aspects that also need to be further studied, such as fracture mechanism, corrosion mechanism, fatigue properties of $\mathrm{Mg} /$ steel joint, etc. Hence, there is still more research to be conducted on the bonding mechanism of magnesium/steel joints. 
Author Contributions: G.S. contributed significantly to the analysis and manuscript preparation. T.L. performed the data analyses and wrote the manuscript. J.Y. contributed to the collection and processing of data. L.L. helped perform the analysis with constructive discussions.

Funding: The authors acknowledge funding from the National Natural Science Foundation of China [No. U1764251] the Natural Science Foundation of Liaoning Province [2015020108].

Conflicts of Interest: The authors declare no conflict of interest.

\section{References}

1. Taban, E.; Gould, J.E.; Lippold, J.C. Dissimilar friction welding of 6061-T6 aluminum and AISI 1018 steel: Properties and microstructural characterization. Mater. Des. 2010, 31, 2305-2311. [CrossRef]

2. Chen, Y.C.; Nakata, K. Friction stir lap joining aluminum and magnesium alloys. Scr. Mater. 2008, 58, 433-436. [CrossRef]

3. Ouyang, J.H.; Yarrapareddy, E.; Kovacevic, R. Microstructural evolution in the friction stir welded 6061 aluminum alloy (T6-temper condition) to copper. J. Mater. Process. Technol. 2006, 172, 110-122. [CrossRef]

4. Fronczek, D.M.; Wojewoda-Budka, J.; Chulist, R.; Sypien, A.; Korneva, A.; Szulc, Z.; Schell, N.; Zieba, P. Structural properties of Ti/Al clads manufactured by explosive welding and annealing. Mater. Des. 2016, 91, 80-89. [CrossRef]

5. Gao, M.; Mei, S.W.; Wang, Z.M.; Li, X.Y.; Zeng, X.Y. Characterisation of laser welded dissimilar Ti/steel joint using Mg interlayer. Sci. Technol. Weld. Join. 2012, 17, 269-276. [CrossRef]

6. Tan, C.; Yang, J.; Zhao, X.; Zhang, K.; Song, X.; Chen, B.; Li, L.; Feng, J. Influence of Ni coating on interfacial reactions and mechanical properties in laser welding-brazing of $\mathrm{Mg} / \mathrm{Ti}$ butt joint. J. Alloys Compd. 2018, 764, 186-201. [CrossRef]

7. Li, L.Q.; Tan, C.W.; Chen, Y.B.; Guo, W.; Hu, X.B. Influence of Zn coating on interfacial reactions and mechanical properties during laser welding-brazing of $\mathrm{Mg}$ to steel. Metall. Mater. Trans. A 2012, 43, 4740-4754. [CrossRef]

8. Liu, L.; Ren, D.; Liu, F. A review of dissimilar welding techniques for magnesium alloys to aluminum alloys. Materials 2014, 7, 3735-3757. [CrossRef]

9. Aizawa, T.; Hasehira, K.I.; Nishimura, C. Solid state synthesis of non-equilibrium phase in $\mathrm{Mg}-\mathrm{Co}$ and $\mathrm{Mg}-\mathrm{Fe}$ systems via bulk mechanical alloying. Mater. Trans. 2003, 44, 601-610. [CrossRef]

10. Xu, R.Z.; Ni, D.R.; Yang, Q.; Xiao, B.L.; Liu, C.Z.; Ma, Z.Y. Influencing mechanism of Al-containing Zn coating on interfacial microstructure and mechanical properties of friction stir spot welded Mg-steel joint. Mater. Charact. 2018, 140, 197-206. [CrossRef]

11. Liu, X.; Wang, X.; Wang, B.; Zhang, L.; Yang, C.; Chai, T. The role of mechanical connection during friction stir keyholeless spot welding joints of dissimilar materials. Metals 2017, 7, 217. [CrossRef]

12. Chen, Y.; Chen, J.; Amirkhiz, B.S.; Worswick, M.J.; Gerlich, A.P. Microstructures and properties of Mg alloy/DP600 steel dissimilar refill friction stir spot welds. Sci. Technol. Weld. Join. 2015, 20, 494-501. [CrossRef]

13. Zhang, Z.K.; Wang, X.J.; Wang, P.C.; Zhao, G. Friction stir keyholeless spot welding of AZ31 Mg alloy-mild steel. Trans. Nonferrous Met. Soc. China 2014, 24, 1709-1716. [CrossRef]

14. Shen, Z.; Ding, Y.; Chen, J.; Gerlich, A.P. Comparison of fatigue behavior in $\mathrm{Mg} / \mathrm{Mg}$ similar and $\mathrm{Mg} /$ steel dissimilar refill friction stir spot welds. Int. J. Fatigue 2016, 92, 78-86. [CrossRef]

15. Jana, S.; Hovanski, Y.; Grant, G.J. Friction stir lap welding of magnesium alloy to steel: A preliminary investigation. Metall. Mater. Trans. A 2010, 41,3173-3182. [CrossRef]

16. Wei, Y.; Li, J.; Xiong, J.; Huang, F.; Zhang, F. Microstructures and mechanical properties of magnesium alloy and stainless steel weld-joint made by friction stir lap welding. Mater. Des. 2012, 33, 111-114. [CrossRef]

17. Chen, Y.C.; Nakata, K. Effect of tool geometry on microstructure and mechanical properties of friction stir lap welded magnesium alloy and steel. Mater. Des. 2009, 30, 3913-3919. [CrossRef]

18. Chen, Y.C.; Nakata, K. Friction stir lap welding of magnesium alloy and Zinc-coated steel. Mater. Trans. 2009, 50, 2598-2603. [CrossRef]

19. Chen, Y.C.; Nakata, K. Effect of surface states of steel on microstructure and mechanical properties of lap joints of magnesium alloy and steel by friction stir welding. Sci. Technol. Weld. Join. 2010, 15, 293-298. [CrossRef] 
20. Schneider, C.; Weinberger, T.; Inoue, J.; Koseki, T.; Enzinger, N. Characterisation of interface of steel/ magnesium FSW. Sci. Technol. Weld. Join. 2011, 16, 100-106. [CrossRef]

21. Lee, C.Y.; Choi, D.H.; Yeon, Y.M.; Jung, S.B. Dissimilar friction stir spot welding of low carbon steel and Al-Mg alloy by formation of IMCs. Sci. Technol. Weld. Join. 2009, 14, 216-220. [CrossRef]

22. Kasai, H.; Morisada, Y.; Fujii, H. Dissimilar FSW of immiscible materials: Steel/magnesium. Mater. Sci. Eng. A 2015, 624, 250-255. [CrossRef]

23. Joo, S. Joining of dissimilar AZ31B magnesium alloy and SS400 mild steel by hybrid gas tungsten arc friction stir welding. Met. Mater. Int. 2013, 19, 1251-1257. [CrossRef]

24. Liyanage, T.; Kilbourne, J.; Gerlich, A.P.; North, T.H. Joint formation in dissimilar Al alloy/steel and Mg alloy/steel friction stir spot welds. Sci. Technol. Weld. Join. 2009, 14, 500-508. [CrossRef]

25. Wang, X.J.; Li, W.H.; Zhao, G. Connection mechanism research on friction stir spot welding without keyhole between magnesium and steel dissimilar alloys. Mater. Res. Innovations 2014, 18. [CrossRef]

26. Uematsu, Y.; Kakiuchi, T.; Tozaki, Y.; Kojin, H. Comparative study of fatigue behaviour in dissimilar Al alloy/steel and $\mathrm{Mg}$ alloy/steel friction stir spot welds fabricated by scroll grooved tool without probe. Sci. Technol. Weld. Join. 2012, 17, 348-356. [CrossRef]

27. Elthalabawy, W.M.; Khan, T.I. Microstructural development of diffusion-brazed austenitic stainless steel to magnesium alloy using a nickel interlayer. Mater. Charact. 2010, 61, 703-712, 1063-1066. [CrossRef]

28. Elthalabawy, W.; Khant, T. Liquid phase bonding of 316L stainless steel to AZ31 magnesium alloy. J. Mater. Sci. Technol. 2011, 27, 22-28. [CrossRef]

29. Elthalabawy, W.M.; Khan, T.I. Eutectic bonding of austenitic stainless steel 316L to magnesium alloy AZ31 using copper interlayer. Int. J. Adv. Manuf. Technol. 2011, 55, 235-241. [CrossRef]

30. Yuan, X.J.; Sheng, G.M.; Luo, J.; Li, J. Microstructural characteristics of joint region during diffusion-brazing of magnesium alloy and stainless steel using pure copper interlayer. Trans. Nonferrous Met. Soc. China 2013, 23, 599-604. [CrossRef]

31. Miao, Y.G.; Han, D.F.; Yao, J.Z.; Li, F. Microstructure and interface characteristics of laser penetration brazed magnesium alloy and steel. Sci. Technol. Weld. Join. 2010, 15, 97-103. [CrossRef]

32. Miao, Y.G.; Han, D.F.; Yao, J.Z.; Li, F. Effect of laser offsets on joint performance of laser penetration brazing for magnesium alloy and steel. Mater. Des. 2010, 31, 3121-3126. [CrossRef]

33. Miao, Y.; Han, D.; Xu, X.; Wu, B. Phase constitution in the interfacial region of laser penetration brazed magnesium-steel joints. Mater. Charact. 2014, 93, 87-93. [CrossRef]

34. Jiang, M.; Gao, M.; Li, G.; Zhang, C.; Zeng, X.Y. Research on laser welding-brazing of dissimilar Mg alloy and stainless steel. Kovove Mater. 2014, 52, 11-17. [CrossRef]

35. Casalino, G.; Guglielmi, P.; Lorusso, V.D.; Mortello, M.; Peyre, P.; Sorgente, D. Laser offset welding of AZ31B magnesium alloy to 316 stainless steel. J. Mater. Process. Technol. 2017, 242, 49-59. [CrossRef]

36. Nasiri, A.M.; Zhou, Y. Effect of Zn interlayer on brazeability of AZ31B-Mg alloy to steel sheet. Sci. Technol. Weld. Join. 2015, 20, 155-163. [CrossRef]

37. Li, L.Q.; Tan, C.W.; Chen, Y.B.; Guo, W.; Mei, C.X. $\mathrm{CO}_{2}$ laser welding-brazing characteristics of dissimilar metals AZ31B Mg alloy to Zn coated dual phase steel with Mg based filler. J. Mater. Process. Technol. 2013, 213, 361-375. [CrossRef]

38. Tan, C.W.; Chen, Y.B.; Li, L.Q.; Guo, W. Comparative study of microstructure and mechanical properties of laser welded-brazed $\mathrm{Mg}$ /steel joints with four different coating surfaces. Sci. Technol. Weld. Join. 2013, 18, 466-472. [CrossRef]

39. Tan, C.W.; Li, L.Q.; Chen, Y.B.; Mei, C.X.; Guo, W. Interfacial microstructure and fracture behavior of laser welded-brazed Mg alloys to Zn-coated steel. Int. J. Adv. Manuf. Technol. 2013, 68, 1179-1188. [CrossRef]

40. Wahba, M.; Katayama, S. Laser welding of AZ31B magnesium alloy to Zn-coated steel. Mater. Des. 2012, 35 , 701-706. [CrossRef]

41. Tan, C.W.; Xiao, L.Y.; Liu, F.Y.; Chen, B.; Song, X.G.; Li, L.Q.; Feng, J.C. Influence of laser power on the microstructure and mechanical properties of a laser welded-brazed $\mathrm{Mg}$ alloy/Ni-coated steel dissimilar joint. J. Mater. Eng. Perform. 2017, 26, 2983-2997. [CrossRef]

42. Interfacial Microstructure of Diode Laser Brazed AZ31B Magnesium to steel Sheet Using a Nickel Interlayer. Available online: https://app.aws.org/wj/supplement/WJ_2013_01_s1.pdf (accessed on 29 September 2018). 
43. Nasiri, A.M.; Chartrand, P.; Weckman, D.C.; Zhou, N.Y. Thermochemical analysis of phases formed at the interface of a Mg alloy-Ni-plated steel joint during laser brazing. Metall. Mater. Trans. A 2013, 44, 1937-1946. [CrossRef]

44. Influence of $\mathrm{Al}$ Interlayer Thickness on Laser Welding of $\mathrm{Mg} /$ Steel. Available online: http:/ / s3.amazonaws. com/WJ-www.aws.org/supplement/WJ_2016_10_s384.pdf (accessed on 29 September 2018).

45. Interfacial Microstructure of Laser Brazed AZ31B Magnesium to Sn-Plated Steel Sheet. Available online: https://app.aws.org/wj/supplement/WJ_2015_03_s61.pdf (accessed on 29 September 2018).

46. Tan, C.W.; Song, X.G.; Meng, S.H.; Chen, B.; Li, L.Q.; Feng, J.C. Laser welding-brazing of Mg to stainless steel: Joining characteristics, interfacial microstructure, and mechanical properties. Int. J. Adv. Manuf. Technol. 2016, 86, 203-213. [CrossRef]

47. Microstructural Characteristics and Mechanical Properties of Fiber Laser Welded-Brazed Mg Alloy-Stainless Steel Joint. Available online: https://s3.amazonaws.com/WJ-www.aws.org/supplement/WJ_2014_10_s399. pdf (accessed on 29 September 2018).

48. Li, L.; Tan, C.; Chen, Y.; Guo, W.; Song, F. Comparative study on microstructure and mechanical properties of laser welded-brazed Mg/mild steel and Mg/stainless steel joints. Mater. Des. 2013, 43, 59-65. [CrossRef]

49. Microstructure and Properties of Laser Brazed Magnesium to Coated Steel. Available online: https: / / uwaterloo.ca/centre-advanced-materials-joining/sites/ca.centre-advanced-materialsjoining/ files/uploads/files/wj-2011_nasiri.pdf (accessed on 29 September 2018).

50. Windmann, M.; Röttger, A.; Kügler, H.; Theisen, W. Laser beam welding of magnesium to coated high-strength steel 22MnB5. Int. J. Adv. Manuf. Technol. 2016, 87, 3149-3156. [CrossRef]

51. Nasiri, A.M.; Lee, M.Y.; Weckman, D.C.; Zhou, Y. Effects of interfacial lattice mismatching on wetting of Ni-plated steel by magnesium. Metall. Mater. Trans. A 2014, 45, 5749-5766. [CrossRef]

52. Wang, X.Y.; Sun, D.Q.; Sun, Y.; Ding, Z.Q. Effects of Cu addition on microstructure characteristics and tensile behaviors of metal inert-gas arc welded Mg-steel dissimilar joints. Mater. Trans. 2015, 56, 1868-1874. [CrossRef]

53. Wang, X.Y.; Sun, D.Q.; Sun, Y. Influence of Cu-interlayer thickness on microstructures and mechanical properties of MIG-welded Mg-steel joints. J. Mater. Eng. Perform. 2016, 25, 910-920. [CrossRef]

54. Wang, X.Y.; Gu, X.Y.; Sun, D.Q.; Xi, C.Y. Interface characteristics and mechanical behavior of metal inert-gas arc welded Mg-steel joints. J. Mater. Res. 2016, 31, 589-598. [CrossRef]

55. Wang, X.Y.; Sun, D.Q.; Yin, S.Q.; Liu, D.Y. Microstructures and mechanical properties of metal inert-gas arc welded Mg-steel dissimilar joints. Trans. Nonferrous Met. Soc. China 2015, 25, 2533-2542. [CrossRef]

56. Liu, S.; Sun, D.; Gu, X.; Li, H. Microstructures and mechanical properties of metal inert-gas arc welded joints of Mg alloy and ultra-high strength steel. J. Mater. Res. 2017, 32, 843-851. [CrossRef]

57. Ren, D.X.; Liu, L.M. Interface microstructure and mechanical properties of arc spot welding $\mathrm{Mg}$-steel dissimilar joint with Cu interlayer. Mater. Des. 2014, 59, 369-376. [CrossRef]

58. Feasibility of Cold-Metal-Transfer Welding Magnesium AZ31 to Galvanized Mild Steel. Available online: https://s3.amazonaws.com/WJ-www.aws.org/supplement/WJ_2013_09_s274.pdf (accessed on 29 September 2018).

59. Cao, R.; Zhu, H.X.; Wang, Q.; Dong, C.; Lin, Q.; Chen, J.H. Effects of zinc coating on magnesium alloy-steel joints produced by cold metal transfer method. Mater. Sci. Technol. 2016, 32, 1805-1817. [CrossRef]

60. Cao, R.; Xu, Q.W.; Zhu, H.X.; Mao, G.J.; Lin, Q.; Chen, J.H.; Wang, P. Weldability and distortion of Mg AZ31-to-galvanized steel SPOT plug welding joint by cold metal transfer method. J. Manuf. Sci. Eng. Trans. ASME 2017, 139, 210011-2100111. [CrossRef]

61. Cao, R.; Chang, J.H.; Huang, Q.; Zhang, X.B.; Yan, Y.J.; Chen, J.H. Behaviors and effects of Zn coating on welding-brazing process of Al-Steel and Mg-steel dissimilar metals. J. Manuf. Processes 2018, 31, 674-688. [CrossRef]

62. Kang, M.; Kim, C.; Kim, Y. Joining of AZ31 magnesium alloy and steel sheet under four different coating conditions based on gas metal arc weld-brazing. Mater. Trans. 2017, 58, 95-102. [CrossRef]

63. Lin, Q.; Yang, F.; Cao, R.; Chen, J.; Guo, T. Wetting and interfacial characteristics of Mg AZ61 Alloy/Galvanized steel in cold metal transfer process. Metall. Mater. Trans. A 2015, 46, 3793-3796. [CrossRef]

64. Chen, J.; Amirkhiz, B.S.; Zhang, R. Continuous nanoscale Al2Fe transition layer strengthened magnesium-steel spot joints. Mater. Lett. 2017, 196, 242-244. [CrossRef] 
65. Ding, M.; Liu, S.S.; Zheng, Y.; Wang, Y.C.; Li, H.; Xing, W.Q.; Yu, X.Y.; Dong, P. TIG-MIG hybrid welding of ferritic stainless steels and magnesium alloys with $\mathrm{Cu}$ interlayer of different thickness. Mater. Des. 2015, 88, 375-383. [CrossRef]

66. Tan, C.W.; Li, L.Q.; Chen, Y.B.; Guo, W. Laser-tungsten inert gas hybrid welding of dissimilar metals AZ31B Mg alloys to Zn coated steel. Mater. Des. 2013, 49, 766-773. [CrossRef]

67. Song, G.; An, G.Y.; Liu, L.M. Effect of gradient thermal distribution on butt joining of magnesium alloy to steel with Cu-Zn alloy interlayer by hybrid laser-tungsten inert gas welding. Mater. Des. 2012, 35, 323-329. [CrossRef]

68. Wang, H.Y.; Song, G. Influence of Adhesive and $\mathrm{Ni}$ on the Interface between $\mathrm{Mg}$ and Fe in the Laser-TIG-Adhesive Hybrid Welding Joint. Int. J. Precis. Eng. Manuf. 2016, 17, 823-827. [CrossRef]

69. Liu, L.M.; Zhao, X. Study on the weld joint of Mg alloy and steel by laser-GTA hybrid welding. Mater. Charact. 2008, 59, 1279-1284. [CrossRef]

70. Liu, L.M.; Qi, X.D.; Zhang, Z.D. The effect of alloying elements on the shear strength of the lap joint of AZ31B magnesium alloy to Q235 steel by hybrid laser-TIG welding technique. Metall. Mater. Trans. A 2012, 43, 1976-1988. [CrossRef]

71. Liu, L.M.; Xu, R.Z. Investigation of corrosion behavior of Mg-steel laser-TIG hybrid lap joints. Corros. Sci. 2012, 54, 212-218. [CrossRef]

72. Qi, X.D.; Liu, L.M. Investigation on Welding Mechanism and Interlayer Selection of Magnesium/Steel Lap Joints. Available online: https://app.aws.org/wj/supplement/wj201101_s1.pdf (accessed on 29 September 2018).

73. Song, G.; Shan, C. Microstructures of laser-tungsten inert gas hybrid welding of dissimilar AZ31 Mg alloy and Q235 steel with Ni as interlayer. Mater. Res. Innovations 2011, 15, 145-149. [CrossRef]

74. Liu, L.M.; Qi, X.D. Strengthening effect of nickel and copper interlayers on hybrid laser-TIG welded joints between magnesium alloy and mild steel. Mater. Des. 2010, 31, 3960-3963. [CrossRef]

75. Qi, X.D.; Liu, L.M. Comparative study on characteristics of hybrid laser-TIG welded AZ61/Q235 lap joints with and without interlayers. J. Mater. Sci. 2010, 45, 3912-3920. [CrossRef]

76. Liu, L.M.; Shan, C. Study on laser-tungsten inert gas hybrid welding of dissimilar Mg alloy and steel with $\mathrm{Ni}$ as interlayer. Materialwiss. Werkstofftech. 2009, 40, 780-783. [CrossRef]

77. Qi, X.; Song, G. Interfacial structure of the joints between magnesium alloy and mild steel with nickel as interlayer by hybrid laser-TIG welding. Mater. Des. 2010, 31, 605-609. [CrossRef]

78. Liu, L.; Qi, X. Effects of copper addition on microstructure and strength of the hybrid laser-TIG welded joints between magnesium alloy and mild steel. J. Mater. Sci. 2009, 44, 5725-5731. [CrossRef]

79. Liu, L.; Qi, X.; Wu, Z. Microstructural characteristics of lap joint between magnesium alloy and mild steel with and without the addition of Sn element. Mater. Lett. 2010, 64, 89-92. [CrossRef]

80. Song, G.; Li, T.; Zhang, Z.; Liu, L. Investigation of unequal thickness Mg/steel butt-welded plate by hybrid laser-tungsten inert gas welding with a Ni interlayer. J. Manuf. Processes 2017, 30, 299-302. [CrossRef]

81. Song, G.; Li, T.; Chi, J.; Liu, L. Bonding of immiscible Mg/steel by butt fusion welding. Scr. Mater. 2018, 157, 10-14. [CrossRef]

82. Song, G.; Yu, J.W.; Li, T.T.; Wang, J.F.; Liu, L.M. Effect of laser-GTAW hybrid welding heat input on the performance of Mg/Steel butt joint. J. Manuf. Processes 2018, 31, 131-138. [CrossRef]

83. Song, G.; Li, T.; Chen, L. The mechanical properties and interface bonding mechanism of immiscible Mg/steel by laser-tungsten inert gas welding with filler wire. Mater. Sci. Eng. A 2018, 736, 306-315. [CrossRef]

84. Manladan, S.M.; Yusof, F.; Ramesh, S.; Zhang, Y.; Luo, Z.; Ling, Z. Microstructure and mechanical properties of resistance spot welded in welding-brazing mode and resistance element welded magnesium alloy/austenitic stainless steel joints. J. Mater. Process. Technol. 2017, 250, 45-54. [CrossRef]

85. Feng, Y.Q.; Li, Y.; Luo, Z.; Ling, Z.X.; Wang, Z.M. Resistance spot welding of Mg to electro-galvanized steel with hot-dip galvanized steel interlayer. J. Mater. Process. Technol. 2016, 236, 114-122. [CrossRef]

86. Min, D.; Yong, Z.; Jie, L. Dissimilar spot welding joints of AZ31-443 ferritic stainless steel with cover plate. Int. J. Adv. Manuf. Technol. 2016, 85, 1539-1545. [CrossRef]

87. Liu, L.; Zou, G.S.; Mori, H.; Esmaeili, S.; Zhou, Y.N. Nanostructure of immiscible Mg-Fe dissimilar weld without interfacial intermetallic transition layer. Mater. Des. 2016, 92, 445-449. [CrossRef]

88. Liu, L.; Xiao, L.; Chen, D.L.; Feng, J.C.; Kim, S.; Zhou, Y. Microstructure and fatigue properties of Mg-to-steel dissimilar resistance spot welds. Mater. Des. 2013, 45, 336-342. [CrossRef] 
89. Liu, L.; Xiao, L.; Feng, J.; Li, L.; Esmaeili, S.; Zhou, Y. Bonding of immiscible Mg and Fe via a nanoscale Fe2Al5 transition layer. Scr. Mater. 2011, 65, 982-985. [CrossRef]

90. Liu, L.; Xiao, L.; Feng, J.C.; Tian, Y.H.; Zhou, S.Q.; Zhou, Y. The mechanisms of resistance spot welding of magnesium to steel. Metall. Mater. Trans. A 2010, 41A, 2651-2661. [CrossRef]

91. Patel, V.K.; Bhole, S.D.; Chen, D.L. Characterization of ultrasonic spot welded joints of Mg-to-galvanized and ungalvanized steel with a tin interlayer. J. Mater. Process. Technol. 2014, 214, 811-817. [CrossRef]

92. Patel, V.K.; Bhole, S.D.; Chen, D.L. Formation of zinc interlayer texture during dissimilar ultrasonic spot welding of magnesium and high strength low alloy steel. Mater. Des. 2013, 45, 236-240. [CrossRef]

93. Santella, M.; Brown, E.; Pozuelo, M.; Pan, T.Y.; Yang, J.M. Details of Mg-Zn reactions in AZ31 to galvanised mild steel ultrasonic spot welds. Sci. Technol. Weld. Join. 2012, 17, 219-224. [CrossRef]

94. Franklin, T.J.; Pan, J.; Santella, M.; Pan, T. Fatigue behavior of dissimilar ultrasonic spot welds in lap-shear specimens of magnesium and steel sheets. SAE Int. J. Mater. Manuf. 2011, 4, 581-588. [CrossRef]

95. Santella, M.; Franklin, T.; Pan, J.; Pan, T.; Brown, E. Ultrasonic spot welding of AZ31B to galvanized mild steel. SAE Int. J. Mater. Manuf. 2010, 3, 652-657. [CrossRef]

96. Patel, V.K.; Chen, D.L.; Bhole, S.D. Dissimilar ultrasonic spot welding of Mg-Al and Mg-high strength low alloy steel. Theor. Appl. Mech. Lett. 2014, 4, 41005. [CrossRef]

97. Lai, W.; Pan, J.; Feng, Z.; Santella, M.; Pan, T. Failure mode and fatigue behavior of ultrasonic spot welds with adhesive in lap-shear specimens of magnesium and steel sheets. SAE Int. J. Mater. Manuf. 2013, 6, 279-285. [CrossRef]

98. Pan, T.; Feng, Z.; Santella, M.; Chen, J. Corrosion behavior of mixed-metal joint of magnesium to mild steel by ultrasonic spot welding with and without adhesives. SAE Int. J. Mater. Manuf. 2013, 6, 271-278. [CrossRef]

(C) 2018 by the authors. Licensee MDPI, Basel, Switzerland. This article is an open access article distributed under the terms and conditions of the Creative Commons Attribution (CC BY) license (http:/ / creativecommons.org/licenses/by/4.0/). 